\title{
Towards a Functional Cure for Diabetes Using Stem Cell-Derived Beta Cells: Are We There Yet?
}

\author{
Stephanie Bourgeois ${ }^{1,+}$, Toshiaki Sawatani ${ }^{2,+}$, Annelore Van Mulders ${ }^{1} \mathbb{D}$, Nico De Leu ${ }^{1,3,4} \mathbb{D}^{D}$, Yves Heremans $^{1}$, \\ Harry Heimberg ${ }^{1}$, Miriam Cnop ${ }^{2,5}$ (D) and Willem Staels $1,6, *$ (D)
}

1 Beta Cell Neogenesis (BENE) Research Group, Vrije Universiteit Brussel (VUB), 1090 Brussels, Belgium; Stephanie.An.B.Bourgeois@vub.be (S.B.); Annelore.An.Van.Mulders@vub.be (A.V.M.); Nico.De.Leu@vub.be (N.D.L.); Yves.Heremans@vub.be (Y.H.); Harry.Heimberg@vub.be (H.H.)

2 ULB Center for Diabetes Research, Medical Faculty, Université Libre de Bruxelles, 1070 Brussels, Belgium; toshiaki.sawatani@ulb.be (T.S.); mcnop@ulb.ac.be (M.C.)

3 Department of Endocrinology, University Hospital Brussels, 1090 Brussels, Belgium

4 Department of Endocrinology, ASZ Aalst, 9300 Aalst, Belgium

5 Division of Endocrinology, Erasmus Hospital, Université Libre de Bruxelles, 1070 Brussels, Belgium

6 Service of Pediatric Endocrinology, Department of Pediatrics, KidZ Health Castle, Universitair Ziekenhuis Brussel (UZ Brussel), 1090 Brussels, Belgium

* Correspondence: willem.staels@vub.be; Tel.: +32-0-24774473

+ These authors contributed equally to this work.

Citation: Bourgeois, S.; Sawatani, T.; Van Mulders, A.; De Leu, N.; Heremans, Y.; Heimberg, H.; Cnop, M.; Staels, W. Towards a Functional Cure for Diabetes Using Stem Cell-Derived Beta Cells: Are We There Yet?. Cells 2021, 10, 191. https://doi.org/10.3390/ cells10010191

Received: 30 November 2020

Accepted: 12 January 2021

Published: 19 January 2021

Publisher's Note: MDPI stays neutral with regard to jurisdictional claims in published maps and institutional affiliations.

Copyright: (c) 2021 by the authors. Licensee MDPI, Basel, Switzerland. This article is an open access article distributed under the terms and conditions of the Creative Commons Attribution (CC BY) license (https:/ / creativecommons.org/licenses/by/ $4.0 /)$.

\begin{abstract}
Diabetes mellitus is a pandemic metabolic disorder that results from either the autoimmune destruction or the dysfunction of insulin-producing pancreatic beta cells. A promising cure is beta cell replacement through the transplantation of islets of Langerhans. However, donor shortage hinders the widespread implementation of this therapy. Human pluripotent stem cells, including embryonic stem cells and induced pluripotent stem cells, represent an attractive alternative beta cell source for transplantation. Although major advances over the past two decades have led to the generation of stem cell-derived beta-like cells that share many features with genuine beta cells, producing fully mature beta cells remains challenging. Here, we review the current status of beta cell differentiation protocols and highlight specific challenges that are associated with producing mature beta cells. We address the challenges and opportunities that are offered by monogenic forms of diabetes. Finally, we discuss the remaining hurdles for clinical application of stem cell-derived beta cells and the status of ongoing clinical trials.
\end{abstract}

Keywords: beta cells; cell therapy; stem cells

\section{Introduction}

Pancreatic beta cells are critical regulators of blood glucose homeostasis by their unique ability to produce and secrete insulin in response to changing blood glucose levels. Because insulin is the only hormone that is able to decrease blood glucose levels, its release into the bloodstream must be strictly controlled in order to prevent blood glucose levels from surpassing dangerously low or high levels. The loss of beta cell function results in diabetes mellitus, a group of metabolic disorders that are characterized by chronically elevated blood glucose levels. Diabetes mellitus has reached epidemic proportions globally and it currently affects over 463-million people [1]. Although its two predominant forms are type 1 (T1D) and type 2 diabetes (T2D), rare forms of diabetes, including monogenic types that require specific attention, are increasingly diagnosed. T1D is marked by absolute insulin deficiency following autoimmune-mediated beta cell loss [2], while T2D is caused by relative insulin deficiency due to beta cell dysfunction, often in the context of peripheral insulin resistance [3]. Monogenic forms of diabetes result from single gene mutations and they are characterized by beta cell dysfunction, to varying degrees of severity [4]. Because no real cure exists for diabetes, daily insulin injections remain the standard of 
care for patients with T1D, late-stage T2D, and for a subset of patients with monogenic diabetes. Although this treatment is lifesaving, it conveys a chronic and costly burden of care, a persisting risk for acute and chronic complications, and it still results in an overall decreased life expectancy.

Beta cell replacement holds the potential to truly cure T1D and also possibly T2D and monogenic diabetes. Such cell therapy-through percutaneous infusion of pancreatic islets into the portal vein-is currently applied in some patients with brittle T1D [5], providing prolonged insulin independence. In selected patients, beta cell replacement proves to be superior to insulin administration with regard to overall metabolic control, prevention of severe hypoglycemia, and delaying the progression of micro- and macrovascular complications [6-9]. Despite this proof-of-principle for beta cell replacement as a genuine cure, donor islet transplantation is unattainable for the vast majority of diabetic patients for several reasons. First, donor islets are in short supply, which contrasts with the global disease prevalence. Donor shortage is further aggravated by a loss of up to half of grafted cells in the first few days after transplantation (reviewed in [10]). Delayed graft revascularization is one of the leading causes for this loss, since, following transplantation, islets enter a poorly vascularized and hypoxic microenvironment [11,12] that compromises islet cell and, in particular, beta cell survival and function. Excessive numbers of beta cells must be grafted to compensate for this early post-transplant cell loss, which further aggravates donor scarcity. Second, the allogenic origin of donor islet grafts necessitates lifelong immunosuppression, thereby increasing the susceptibility to infections and tumorigenesis (reviewed in [13]).

This donor islet shortage has fueled the search for alternative beta cell sources. Recent advances in differentiation protocols have positioned human embryonic stem cells (ESCs) and human induced pluripotent stem cells (iPSCs) as a promising and theoretically unlimited beta cell source. Currently, encapsulated pancreatic endoderm cells, differentiated from human ESCs, have already entered the first clinical trials (NCT03162926 (completed), NCT03163511 (recruiting), NCT02239354 (active, not recruiting), and NCT02939118 (enrolling by invitation)) and some preliminary results have been disseminated [14]. In this review, we define some key characteristics of adult beta cells and call attention to heterogeneity within the beta cell population. Next, we discuss the use of stem cells as an alternative beta cell source for transplantation. We elaborate on the current status of stem cell differentiation protocols in order to generate beta cells, the cues that are needed for functional beta cell maturation, and a number of hurdles that still need to be overcome. We address the following hurdles in detail: (i) the limited functional maturation of in vitro generated beta cells, (ii) the difficulties of graft survival upon transplantation due to the immune response and delay in graft revascularization, and (iii) safety concerns, especially regarding residual immature cells that may give rise to teratoma formation. Finally, we highlight the potential of gene-editing to generate patient- or disease-tailored beta(-like) cells for personalized medicine, discuss ongoing clinical trials, and offer some perspectives to the field.

\section{Beta Cell Maturation and Heterogeneity}

\subsection{The Mature Beta Cell}

Because the ultimate goal of stem cell differentiation protocols in diabetes research is to generate mature, fully functional beta cells, it is important to define what constitutes a functionally mature beta cell. The foremost fundamental characteristic of a beta cell lies in its ability to secrete appropriate amounts of insulin in response to glucose. Beta cells have a specialized machinery for fulfilling this role. In brief, glucose uptake by beta cells is mediated by specialized low affinity glucose transporters (mainly GLUT1 in human). Upon entry, glucose is phosphorylated by glucokinase (GCK) and is used to generate ATP through oxidative phosphorylation. This rise in ATP increases the ATP/ADP ratio, which, in turn, leads to the closure of ATP-sensitive potassium $\left(\mathrm{K}_{\mathrm{ATP}}\right)$ channels and cell membrane depolarization. The latter electric signal then triggers the opening of voltage-dependent 
calcium channels (VDCCs), leading to $\mathrm{Ca}^{2+}$ influx, resulting in the release of insulin granules through exocytosis $[15,16]$. Subsequently, beta cells generate a second, even larger, wave of insulin release (known as biphasic glucose-stimulated insulin secretion) that is $\mathrm{K}_{\mathrm{ATP}}$-channel independent, but rather beta cell metabolism-dependent [17-19]. Mature beta cells can generate such responses-in a uniquely sensitive way-to minor physiological variations in plasma glucose levels.

Testing the maturity of beta cells with functional assays that interrogate the specialized cellular machinery that is implicated in glucose sensing and insulin secretion while using physiologically relevant variations in glucose concentrations is cumbersome, time-consuming, and often difficult. Therefore, cell markers have been used as surrogate measures for beta cell maturation. Typical beta cell maturation markers include the transcription factors GLIS3 [20], MAFA [21], NEUROD1 [22], NKX6.1 [23], PAX6 [24], PDX1 [25], SIX2 [26], and UCN3 [27,28]. Notably, besides positive regulators, beta cell maturity is equally determined by the absence of 'disallowed' or 'forbidden' genes that interfere with beta cell function including Ldha, Mct1, SLC16A1, Hk1, Hk2, and Rest (reviewed in [29]). The disallowed genes are upregulated under mild hyperglycemia as deduced from scRNA-seq data of beta cells isolated from diabetic rats, pointing to beta cell dysfunction occurring already in the early stages of diabetes [30]. In addition, one of the most important aspects of adult beta cells is their post-mitotic nature. Beta cell mass expansion mainly occurs shortly after birth by a process that rapidly declines with age [31,32], to reach an extremely low proliferation rate of $0.1-0.4 \%$ in the adult human [33,34]. Mathematical modeling of the accumulation of lipofuscin bodies in human beta cells suggests that, after the age of 20 years, long-lived beta cells age with the body [35,36].

\subsection{Heterogeneity in the Adult Beta Cell Population}

A next level of complexity with regard to the adult beta cell population is its heterogenous nature. The concept of beta cell heterogeneity was developed in the 1990s following metabolism-centered studies of dissociated cell populations, wherein some beta cells showed differential glucose-responsiveness $[37,38]$ based on differences in glucokinase activity [39]. Recent studies unveiled particular underlying molecular hallmarks to provide compelling examples of beta cell heterogeneity. For example, Johnston et al. identified two distinct beta cell populations, 'hub' or 'leader' cells ( $<10 \%$ of beta cells), with pacemaker properties that orchestrate the electrophysiological responses of 'follower' cells ( $>90 \%$ of beta cells) upon insulin secretion challenges. Leader cells display high-potential mitochondria, high glucokinase expression, reduced insulin content, and lower expression of the beta cell markers PDX1 and NKX6.1 [40]. Bader et al. identified two distinct beta cell subpopulations that are based on the expression of Flattop (Fltp), a Wnt/planar cell polarity (PCP) effector, and reporter gene. Fltp ${ }^{-}$beta cells are more proliferative and able to expand under conditions of increased metabolic demand, such as pregnancy, whereas Fltp ${ }^{+}$beta cells are more mature, and they display higher insulin secretory capacity and increased mitochondrial function [41]. van der Meulen et al. identified immature beta cells in a neogenic niche at the adult islet periphery that lack $\mathrm{UCN} 3$ and are derived from transdifferentiated alpha cells [42]. Because these UCN3-negative beta cells only constitute $1.5 \%$ of the total beta cell population, they are likely distinct from the more abundant leader or follower cells and from the Fltp ${ }^{+}$and Fltp ${ }^{-}$beta cells, since the latter express UCN3 [41].

\section{General Properties of Stem Cells}

Stem cells are clonal cells with the potential to both self-renew and differentiate into a variety of functional somatic cells [43]. Stem cells are classified into three main types, according to their origin, potential, and developmental stage, as: (i) ESCs-which are isolated from the early mammalian embryo, (ii) adult stem cells-which can be found in various adult tissues (e.g., neural, hematopoietic, mesenchymal, and epidermal stem cells), and (iii) iPSCs - which are derived from adult cells that are reprogrammed back to an embryonic-like pluripotent state. 
ESCs are highly undifferentiated cells that are isolated from the inner cell mass of mammalian blastocysts, i.e., early embryonic cells. ESCs can, on the one hand, proliferate indefinitely while maintaining their pluripotency and on the other differentiate into cells of all three germ layers [44]. In 1998, Thomson et al. established ESC lines from human blastocysts [45]. Because human ESCs can be maintained in culture for extended periods of time and can be differentiated into any desired target cell type, they represent a promising cell source for regenerative medicine to treat a host of diseases, including Parkinson's disease, spinal cord injury, and diabetes [45]. However, even if functional cells and organs can be generated from ESCs, their transplantation remains subject to allograft rejection in the same manner as conventional donor organ transplants. Because human ESCs are derived from surplus human embryos, their application in regenerative medicine also raises ethical concerns that can be addressed by the use of iPSCs that are generated by reprogramming somatic cells, such as peripheral blood mononuclear cells or dermal fibroblasts, into the pluripotent state through the overexpression of a defined set of transcription factors (Oct4, Sox2, Klf4, and c-Myc) [46]. Such a straightforward method to produce human iPSCs directly from patients' own cells opens the possibility of studying disease and screening drugs in vitro in a patient-specific manner. In addition, the inherent autologous nature of iPSCs provides them with unique immunological advantages over other cell sources in the context of cell therapy.

\section{Current Status of Human ESC and iPSC Differentiation Protocols}

The discovery of ESCs and iPSCs has opened the possibility to generate cells or tissues in vitro that can be used for the study of disease mechanisms, drug screening, and cell replacement. Regarding the latter, these cells promise an unlimited source of virtually any cell type that can be transplanted into patients, including pancreatic beta cells for people with diabetes.

\subsection{Generation of Stem Cell-Derived Beta Cells}

The main approach for differentiating stem cells into beta cells is by adherent cell culture with progressive, stepwise lineage commitment while using combinations of cues added to the culture medium. Using such an in vitro lineage differentiation approach, D'Amour et al. were the first to succeed in robust induction of definitive endoderm differentiation [47], with subsequent generation of pancreatic endocrine hormone-producing cells [48]. However, the endocrine cells that were generated were mainly polyhormonal (e.g., insulin and glucagon co-expressing cells) that are more akin to immature islet cells [49]. The resulting insulin-expressing cells also lacked the essential beta cell transcription factors NKX6.1 and PDX1 [50]. Over the ensuing years, strategies have been devised and optimized in order to generate monohormonal insulin-expressing cells that co-express NKX6.1 and PDX1 by modifying the composition and timing of growth factor and small molecule addition [51-53]. In 2014, Rezania et al. [53] and Pagliuca et al. [52] reported the successful generation of functional stem cell-derived beta-like cells that possessed many beta cell-specific traits, including glucose-responsive insulin secretion. Importantly, the transplantation of these cells was able to reverse diabetes in mice. However, the beta-like cells that were generated by these protocols $[52,53]$ and follow-up studies $[51,54-56]$ still displayed poor glucose-induced insulin secretion when compared to human islets.

More recently, Nair et al. [57] and Velazco-Cruz et al. [58] succeeded in generating functional human stem cell-derived beta cells showing dynamic glucose-stimulated insulin secretion that is similar to human islets. Nair et al. reaggregated immature human stem cell-derived beta-like cells into enriched-beta cell clusters after fluorescence-activated cell sorting (FACS) and demonstrated that the reaggregation/clustering is paramount to the generation of functionally superior beta cells with robust dynamic insulin secretion in vitro [57]. Mechanistically, the clustering of beta-like cells induced metabolic maturation by driving mitochondrial oxidative respiration, which is central to stimulus-secretion coupling in mature beta cells. This strategy not only increased the structural resemblance 
with native islets, but also the functional resemblance, both at the cellular (transcriptomic) and cluster (functional) level [57]. Velazco-Cruz et al. mainly focused on permitting TGF- $\beta$ signaling during the final stage of differentiation (from endocrine progenitor to beta-like cell) and, additionally, on controlling cellular cluster size [58]. Although the TGF- $\beta$ pathway is claimed to play a critical role during beta cell differentiation from stem cells [59], its role in beta cell function and insulin secretion remains controversial, as TGF- $\beta$ signaling suppresses insulin transcription and reduces insulin protein levels and secretion [60], while others posited that TGF- $\beta$ signaling is required for maintaining beta cell mass and regulating insulin secretion $[61,62]$. Further studies on TGF- $\beta$ signaling in beta cells are needed, but, with respect to the differentiation of highly functional beta cells from stem cells, TGF- $\beta$ fulfills a dual role, as its inhibition is required at early stages while its signaling is beneficial at late stages. Recently, Yoshihara et al. demonstrated that non-canonical WNT4 signaling drives the metabolic maturation of beta-like cells-essential for robust insulin secretion-in large part through the induction of an ERRgamma gene network [63], while Li et al. developed a beta cell differentiation protocol that is based on three previously published protocols $[52,53,64]$ to obtain beta cells with high glucose-responsiveness and insulin production [65].

In addition to maturity, the purity of beta cells that are differentiated from human pluripotent stem cells must be taken into account for in vitro differentiation protocols, since a higher percentage of differentiated cells implies a lower percentage of contaminating immature and therefore possibly teratogenic cells. Sorting strategies while using a GFP reporter under the control of the insulin gene promoter or an antibody to the beta cell surface marker CD49a enabled obtaining $80-90 \%$ pure beta cells $[57,66]$. Alternatively, the cell-surface marker CD9 can be exploited for negative selection to enrich for glucoseresponsive human beta-like cells [65]. These strategies may also prove to be useful for sorting other hormone-producing cells, such as alpha cells, which contribute to disease etiology by elevating blood glucose levels [67-69]. See Table 1 for a summary of the approaches for the generation and purification of stem cell-derived beta cells.

\subsection{Generation of Non-Beta Pancreatic Endocrine Cell Types}

Co-transplantation with other pancreatic endocrine cell types will likely benefit transplantation outcomes, as the release of insulin is regulated via complex paracrine interactions (discussed in more detail in the next chapter). To this end, efforts are ongoing for generating non-beta pancreatic endocrine cell types. In 2011, the directed differentiation of human ESCs into glucagon-positive cells, expressing the key alpha cell transcription factor ARX was reported [73]. Although these alpha-like cells secreted glucagon in vitro to some extent, proper regulation was lacking, which is indicative of their immature state [73]. More recently, Peterson et al. developed a differentiation protocol for the generation of alpha cells that express and secrete glucagon in response to low glucose and some glucagon secretagogues, and that elevate blood glucose levels upon transplantation in mice [74]. Efforts to develop differentiation protocols for somatostatin-producing delta cells, ghrelin-producing epsilon cells, and pancreatic polypeptide cells, and cell surface antibody-based sorting strategies will further contribute to the generation of islet-like clusters that will provide a unique resource for studying cell biology, disease modelling, drug screening, and cell replacement therapy. 
Table 1. Overview of protocols for the generation of stem cell-derived beta cells.

\begin{tabular}{|c|c|c|c|}
\hline Report & Approach & Outcome to Beta-Cell Function & Reference \\
\hline Pagliuca et al., 2014 & $\begin{array}{l}\text { Protocol for generation of } \\
\text { beta-like cells by modifying and } \\
\text { combining three previous } \\
\text { protocols }[70-72]\end{array}$ & $\begin{array}{l}\text { Expression of key markers of mature } \\
\text { pancreatic beta-cells, glucose-induced } \mathrm{Ca}^{2+} \\
\text { influx, insulin secretion in response to } \\
\text { multiple sequential glucose challenges }\end{array}$ & {$[52]$} \\
\hline Rezania et al., 2014 & $\begin{array}{l}\text { 7-stage protocol for generation of } \\
\text { beta-like cells based on previous } \\
\text { own protocol [70] }\end{array}$ & $\begin{array}{l}\text { Expression of key markers of mature } \\
\text { pancreatic beta-cells, insulin secretion in } \\
\text { response to high glucose }\end{array}$ & [53] \\
\hline Russ et al., 2015 & $\begin{array}{l}\text { Protocol for generation of } \\
\text { beta-like cells based on two } \\
\text { previous protocols [70] by culture } \\
\text { without additional growth factors } \\
\text { after endocrine progenitor stage }\end{array}$ & $\begin{array}{l}\text { Expression of key markers of mature } \\
\text { pancreatic beta-cells, insulin secretion in } \\
\text { response to high glucose }\end{array}$ & {$[51]$} \\
\hline Millman et al., 2016 & $\begin{array}{l}\text { Addition of ROCK inhibitor and } \\
\text { Activin A based on [52] at } \\
\text { pancreatic progenitor stage }\end{array}$ & $\begin{array}{l}\text { Similar to their previous studies [52], } \\
\text { beneficial effect on insulin expression and } \\
\text { secretion }\end{array}$ & [56] \\
\hline Zhu et al., 2016 & $\begin{array}{l}\text { Addition of vitamin C and } \\
\text { BayK-8644 at final stage }\end{array}$ & Increased insulin expression and secretion & {$[55]$} \\
\hline Ghazizadeh et al., 2017 & $\begin{array}{l}\text { ROCKII inhibition at pancreatic } \\
\text { progenitor stage }\end{array}$ & $\begin{array}{l}\text { Generation and maturation of } \\
\text { glucose-responsive cells }\end{array}$ & [54] \\
\hline Nair et al., 2019 & $\begin{array}{l}\text { Reaggregation/clustering after } \\
\text { FACS at final stage }\end{array}$ & $\begin{array}{l}\text { Robust dynamic insulin secretion, metabolic } \\
\text { maturation by driving mitochondrial } \\
\text { oxidative respiration }\end{array}$ & [57] \\
\hline Velazco-Cruz et al., 2019 & $\begin{array}{l}\text { Allowing TGF- } \beta \text { signaling during } \\
\text { the final stage and } \\
\text { reaggregation/clustering }\end{array}$ & $\begin{array}{l}\text { Pure populations of beta-like cells that } \\
\text { secrete high levels of insulin and express key } \\
\text { beta cell markers }\end{array}$ & [58] \\
\hline Yoshihara et al., 2020 & $\begin{array}{c}\text { Allowing WNT4 signaling during } \\
\text { the final stage }\end{array}$ & $\begin{array}{l}\text { Metabolic maturation with robust insulin } \\
\text { secretion and high mitochondrial oxidative } \\
\text { respiration }\end{array}$ & [63] \\
\hline Li et al., 2020 & $\begin{array}{l}\text { Combination of three previous } \\
\text { protocols [52], and } \\
\text { reaggregation/clustering after } \\
\text { negative sorting by CD9 }\end{array}$ & $\begin{array}{l}\text { High glucose-responsiveness and insulin } \\
\text { production }\end{array}$ & {$[65]$} \\
\hline
\end{tabular}

ROCK: Rho-associated protein kinase, TGF- $\beta$ : transforming growth factor $\beta$, FACS: fluorescence-activated cell sorting, WNT4: winglesstype murine-mammary-tumour virus integration site family member 4, CD9: cluster of differentiation 9.

\section{Current Hurdles for Stem Cell Therapy and Possible Ways to Tackle Them}

\subsection{Functional Immaturity of Stem Cell-Derived Beta Cells}

Beta cells reside within the pancreatic islets of Langerhans, being clustered together along with alpha, delta, epsilon, and pancreatic polypeptide cells. Beta cells intensively interact with a variety of cell types in their microenvironment, including the other endocrine and non-endocrine cells within the islet, but also with exocrine cells outside the islet. The numerous signals that beta cells receive are crucial for their functionality, survival, differentiation, and proliferation. First, beta-to-beta cell interactions are of major importance for a properly coordinated and synchronized insulin secretory response and for insulin gene expression, storage, biosynthesis, and release [75-77]. Paracrine cell interactions between different endocrine islet cell types are also paramount in fine-tuning the islet secretory response. [78,79]. Indeed, glucagon is a well-known regulator of insulin secretion, whereas somatostatin inhibits both insulin and glucagon secretion [27]. The importance of inter-endocrine cell-to-cell contacts for beta cell maturation is demonstrated by the enhanced maturation of human stem-cell-derived beta cells upon in vitro mimicking of cell clustering [57]. Therefore, the transplantation of islet-like clusters, rather than just beta cells alone, is likely to benefit glycemic control. Besides interactions with other endocrine 
cells, beta cells also receive signals from the extracellular matrix [80], endothelial cells [81], pericytes [82], neurons [83,84], and immune cells [85].

All of these cues from the islet microenvironment are essential for beta cell maturation. Notably, differentiation does not equal maturation, as Potten and Loeffler stated in 1990: "Differentiation can be defined as a qualitative change in the cellular phenotype that is the consequence of the onset of synthesis of new gene products, that lead ultimately to functional competence. Maturation in contrast can be regarded as a quantitative change in the cellular phenotype or the cellular constituent proteins leading to functional competence" [86]. This notion implies that, even when stem cell-derived beta cells express all known adult beta cell markers and produce high levels of insulin, they are not per se functionally mature, since the proof of functionality should be sought in functional tests that dynamically interrogate the beta cell glucose sensing and insulin secretory machinery.

It is very difficult, if not impossible, to provide all of the signals that beta cells receive from their microenvironment through simplified in vitro differentiation protocols, which is why current protocols rely on in vivo maturation for beta cells to become functional $[52,53]$. An alternative approach seeks not to generate mature cells, but uses early definitive endoderm or pancreatic progenitor cells and relies strongly on self-directed differentiation and maturation in order to obtain a functional stem cell-derived beta cell mass in vivo [70,87,88]. This is the strategy that was also chosen in the ongoing clinical trials, as mentioned in the introduction. However, while using this approach, it will take several months for the beta cells to become functional and this black box of in vivo maturation does not allow for an easy dissection of its mechanisms. Augsornworawat et al. performed single-cell RNA sequencing on human iPSC- and ESC-islet grafts that were transplanted for six months in diabetic mice and compared their gene expression profiles to stage 6 [89] ungrafted hPSC- islets and cadaveric human islets. The analyses confirmed that transplanted stem cell-derived beta cells possessed insulin secretory capacity and acquired expression of the beta cell maturation markers INS, G6PC2, MAFA, MNX1, SIX2, and UCN3 [90]. Such studies provide a comprehensive resource for understanding human beta cell maturation and to improve differentiation strategies.

Ensuring quick islet revascularization following transplantation will likely benefit beta cell survival and functionality. Endothelial cell-derived signals are crucial for embryonic beta cell development $[81,91]$ and for adult beta cell proliferation, survival, differentiation, and function [81]. Hypovascularization is not only one of the factors contributing to islet cell loss following transplantation, but it may also lead to beta cell dedifferentiation, since intraportal implants of human primary beta cells lose their mature phenotype and expression of key beta cell markers [92]. Strategies for improving graft revascularization have focused on the delivery of pro-angiogenic factors, primarily vascular endothelial growth factor A (VEGF-A), to islet cells. VEGF-A is a key angiogenic factor that is secreted by beta cells to promote endothelial cell migration, proliferation, and survival, and to regulate vascular permeability [81]. VEGF-A protein can be delivered in many ways, but one particularly interesting approach is by the transfection of Vegfa mRNA. Not only is this approach much safer when compared to viral-vector based gene delivery methods, its inherent short-term expression is beneficial as compared to long-term expression [93], which is detrimental for islet function and survival [94]. Recent work from our group showed that liposome-mediated transfection of human and mouse islet cells with synthetic modified Vegfa mRNA improves graft revascularization and increases beta cell mass [95].

Taken together, signals from the islet microenvironment are crucial in ensuring proper beta cell maturation and functionality. The translation of these insights to stem cell differentiation protocols is expected to improve transplantation outcomes.

\subsection{Risk of Tumorigenesis}

The therapeutic potential of pluripotent stem cells is vast, and it promises to transform medicine. The capacity of stem cells to self-renew and differentiate into any desired cell type underlies this promise, but these desirable features also bring along dangers, such as 
a risk of developing tumors. Therefore, several methods and tools have been developed for guaranteeing safety in therapeutic applications of human ESCs and iPSCs. First, tumorigenesis can be prevented by transplanting only differentiated cells. By using techniques, such as endocrine cell clustering and targeting specific signaling, recent differentiation protocols aim to generate higher percentages of mature functional beta cells and minimize the number of undifferentiated progenitor cells, as discussed above. Thus, protocol optimization in terms of improved differentiation minimizes the risk for tumorigenesis. Second, approaches for eliminating or sorting out undifferentiated human pluripotent stem cells in vitro have been developed, such as the use of chemical inhibitors [96], immunological targeting of undesired cell types [97-99], or the introduction of suicide-genes in the stem cell genome [100,101].

Chemical eradication of undifferentiated stem cells is possible by adding small molecules to the culture medium to selectively kill pluripotent cells. A high-throughput screen identified inhibitors of the key oleate biosynthesis enzyme stearoyl-CoA desaturase (SCD1) as agents that specifically compromise stem cell viability [96]. Knowing that SCD1 is abundantly expressed in iPSC-beta cells and required for beta cell identity, the effect of these SCD1 inhibitors on beta cell function warrants further investigation [102]. The immunological targeting of undifferentiated stem cells relies on the use of (cytotoxic) antibodies that are directed against specific stem cell markers to either kill them or separate them from differentiated cells. SSEA-5 glycan, for example, is a human ESC surface marker that has been used in order to selectively remove undifferentiated teratoma-forming cells prior to transplantation [97]. Gene editing can also aid in the removal of undifferentiated human pluripotent stem cells. In an innovative approach to selectively remove tumorigenic cells, two suicide gene cassettes were introduced in ESC-derived beta cells. The first safety cassette was a herpes simplex virus thymidine kinase (HSV-TK) that was driven by the telomerase gene promoter that is selectively active in undifferentiated cells, the second a nitroreductase (NTR) flanked by two loxP-sites, which is removed upon Cre-expression that is driven by the human insulin gene promoter. HSV-TK and NTR are sensitive to, respectively, ganciclovir and CB1954, which enables the elimination of tumorigenic undifferentiated cells at any desired moment, both in vitro and in vivo [100]. Finally, engineered human iPSCs with an inducible Caspase-9 suicide gene have been developed, in which the small molecule chemical inducer of dimerization can effectively induce apoptosis in $>99 \%$ of the cells [101]. While these methods are innovative and promising, they are not a validated approach for guaranteeing safety after clinical transplantation. See Table 2 for an overview of the possible approaches to prevent teratoma formation.

\subsection{Graft Immune Rejection}

Another major hurdle for the clinical application of stem cell-derived beta cells is immune rejection of the graft due to human leukocyte antigen (HLA)-mismatching. Patients currently depend on immune-suppressive drugs for preventing allograft immunity. These drugs can have side-effects, some minor, such as mouth ulcers, diarrhea, and acne, and some serious, including an increased risk for severe infection and malignancy (reviewed in [13]). Allograft rejection could be prevented if patient-specific iPSC derivates are transplanted, which guarantee perfect HLA-matching. However, the production of such personalized cells for individual patients would be very costly, time consuming, and is unlikely to become the universal solution for diabetes in the short term. To this end, HLA banks are currently being set up [103]. These banks contain a selected number of cell lines with homozygous HLA haplotypes that have been carefully chosen to match the majority of the population. The establishment of cell line banks decreases the number of cell lines required for matching to allow transplantation between a genetically unrelated donor and recipient and would thus make stem cell therapy more widely accessible [103-105]. 
Table 2. Approaches to prevent teratoma formation of stem cell-derived grafts.

\begin{tabular}{|c|c|c|c|}
\hline Approach & Target & Intervention & Reference \\
\hline \multirow{5}{*}{$\begin{array}{l}\text { Optimization of } \\
\text { differentiation }\end{array}$} & Oxygen supply & $\begin{array}{l}\text { 7-stage protocol including culture at } \\
\text { air-liquid interface }\end{array}$ & [53] \\
\hline & \multirow{3}{*}{ Signaling pathways } & $\begin{array}{l}\text { Sequential modulation of signaling } \\
\text { pathways in a 3D cell culture system }\end{array}$ & {$[52]$} \\
\hline & & $\begin{array}{l}\text { Removal of BMP inhibitors in combination } \\
\text { with retinoic acid and EGF/KGF addition }\end{array}$ & [51] \\
\hline & & Modulation of TGF- $\beta$ signaling & [58] \\
\hline & Cell clustering & $\begin{array}{l}\text { Isolation and reaggregation of immature } \\
\text { beta-like cells to form islet-sized beta } \\
\text { cell-enriched clusters }\end{array}$ & [57] \\
\hline \multirow{7}{*}{$\begin{array}{l}\text { Elimination of } \\
\text { remaining } \\
\text { undifferentiated cells }\end{array}$} & Chemical methods & Addition of PluriSln 1 & [96] \\
\hline & \multirow{4}{*}{ Immunological methods } & Antibodies against SSEA-5 glycan & [97] \\
\hline & & $\begin{array}{l}\text { Antibodies against beta cell surface marker } \\
\text { CD49a followed by MACS }\end{array}$ & {$[66]$} \\
\hline & & Removal of Claudin-6-positive cells & [99] \\
\hline & & $\begin{array}{l}\text { Separation of SSEA-4 and TRA-1-60 } \\
\text { undifferentiated cells by MACS and FACS }\end{array}$ & [98] \\
\hline & \multirow{2}{*}{ Genetic methods } & Double suicide cassette: HSV-TK and NTR & [100] \\
\hline & & Inducible Caspase-9 suicide gene & [101] \\
\hline
\end{tabular}

BMP: bone morphogenetic proteins, EGF: epidermal growth factor, FACS: fluorescence-activated cell sorting, HSV-TK: herpes simplex virus thymidine kinase, KGF: keratinocyte growth factor, MACS: magnetic-activated cell sorting, NTR: nitroreductase, PluriSln1: pluripotent cell-specific inhibitors, SSEA: stage-specific embryonic antigen, TGF- $\beta$ : transforming growth factor $\beta$.

Alternatively, regulatory T-cell therapy represents an attractive approach to establish immune tolerance to allogeneic grafts and to bypass ongoing autoimmunity upon transplantation. The administration of regulatory T-cells to new-onset diabetic mice can delay autoimmune diabetes and it prolongs islet allograft survival [106]. Clinical trials in T1D patients have already documented the therapeutic efficiency and safety of this approach $[107,108]$. Human regulatory T-cells can be isolated, cultured, and expanded ex vivo before transplantation; however, manufacturing the cells in therapeutically relevant numbers while maintaining high purity remains challenging (reviewed in $[109,110]$ ). Regulatory T-cells secrete multiple anti-inflammatory cytokines, some of which are in clinical use. Recently, beta cells have been engineered while using CRISPR/Cas9 to secrete the anti-inflammatory cytokine interleukin-10 (IL-10). The IL-10 gene was knocked into the C-peptide locus of the Ins1 gene, which results in its transcription, translation, and secretion in a glucose-dependent manner [111]. IL-10, being delivered via an adeno-associated viral vector, is also known to promote islet graft survival upon transplantation in diabetic mice [112].

Another strategy for inducing immune tolerance involves the co-engraftment of selected cell types, such as mesenchymal stem cells (MSCs), which possess beneficial characteristics, including angiogenetic potential and the modulation of the immune response. Therefore, it is not surprising that the co-transplantation of islets with MSCs improves graft survival [113]. Studies that were performed in different experimental models, ranging from mouse [114,115], rat [116], and even non-human primate [117], illustrated that the co-engraftment of islets with MSCs prevents immune rejection through the inhibition of effector T-cells, expansion of regulatory T-cells and decreased pro-inflammatory cytokine production. In a clinical setting, islet transplantation is performed via the hepatic portal vein. However, this strategy does not allow for co-engraftment with MSCs, since the transplanted islets will lodge into the hepatic microcirculation, while the MSCs would end up in the lungs due to their small size. Therefore, the clinical applicability of this 
approach remains limited. The pre-treatment of islets with a cell-free cocktail of MSCderived products has been demonstrated to suppress the immune response and promote transplantation outcomes (reviewed in [118]). This strategy can be easily implemented in transplantation protocols and it surpasses logistic and safety-related disadvantages of MSC co-engraftment [118-120].

Alternatively, interference with HLA gene expression can render human pluripotent stem cells hypoimmunogenic. By CRISPR/Cas9-mediated deletion of the accessory chain beta-2-microglobulin, cells lacking HLA class I molecules can be generated [121]. In addition, the inactivation of the CIITA gene, which encodes the 'class II, major histocompatibility complex, transactivator', can inhibit HLA class II expression [122]. Unfortunately, the deletion of beta-2-microglobulin also prevents HLA-E and HLA-G surface expression, which are essential in sustaining tolerance to natural killer cells. For this reason, Han et al. only deleted HLA-A/B- and C-genes in order to prevent CD8+ T cell-mediated cytotoxicity while maintaining natural killer cell tolerance [123]. Besides knocking out the HLA-A/-B/$\mathrm{C}$ and CIITA genes while using multiplex genome editing, they additionally introduced the immunomodulatory factors PD-L1, HLA-G, and CD47. CD47 is a macrophage 'do not eat me' signal that prevents cell engulfment by macrophages [123]. A selection of attractive strategies to tackle immune rejection of stem cell-derived cellular grafts is compiled in Table 3. Additionally, see Figure 1 for a schematic summary of the current hurdles for stem cell therapy and their possible solutions. 
Table 3. Approaches to prevent immune rejection of stem cell-derived grafts.

\begin{tabular}{|c|c|c|c|c|c|}
\hline Point of Action & Approach & Intervention & $\begin{array}{c}\text { Species } \\
\text { (Graft to Host) }\end{array}$ & Outcome & Reference \\
\hline \multirow{14}{*}{ Graft } & \multirow{6}{*}{ Hypo-immunity } & \multirow{2}{*}{ Deletion of $\beta 2 \mathrm{M}$} & \multirow{2}{*}{$\begin{array}{l}\text { B2M knock-out ESCs } \\
\text { transplanted in NK-cell } \\
\text { depleted mice }\end{array}$} & $\begin{array}{l}\text { (+) Prevents immune rejection, confers resistance to T-cell } \\
\text { mediated killing }\end{array}$ & \multirow{2}{*}{ [124] } \\
\hline & & & & (-) Loss of NK-tolerance & \\
\hline & & \multirow{2}{*}{ Deletion of $\beta 2 \mathrm{M}$ and CIITA } & \multirow{2}{*}{$\begin{array}{l}\text { HLA-1/2 knock-out iPSCs } \\
\text { in vitro }\end{array}$} & $\begin{array}{l}\text { (+) Eliminates immunogenicity, universal donor cell } \\
\text { therapy potential }\end{array}$ & \multirow{2}{*}{ [122] } \\
\hline & & & & (-) Loss of NK-tolerance & \\
\hline & & \multirow{2}{*}{$\begin{array}{l}\text { Deletion of HLA-A/-B/-C } \\
\text { and CIITA + PD-L1, HLA-G } \\
\text { and CD47 upregulation }\end{array}$} & \multirow{2}{*}{$\begin{array}{l}\text { Engineered human stem cells } \\
\text { transplanted in mice }\end{array}$} & $\begin{array}{c}\text { (+) Less immune activation, decreases T-\& NK-cell } \\
\text { mediated killing and macrophage engulfment }\end{array}$ & \multirow{2}{*}{ [123] } \\
\hline & & & & (-) Complex genetic engineering, risk of off-target events & \\
\hline & \multirow{3}{*}{$\begin{array}{l}\text { Immune-checkpoint } \\
\text { modulation }\end{array}$} & \multirow{2}{*}{$\begin{array}{l}\text { SA-PD-L1 engineered islet } \\
\text { grafts }\end{array}$} & \multirow{2}{*}{$\begin{array}{l}\text { SA-PDL1 mouse islets } \\
\text { transplanted in mice }\end{array}$} & $\begin{array}{l}\text { (+) Sustains graft survival, prevents allograft immune } \\
\text { rejection, confers localized immunomodulation }\end{array}$ & \multirow{2}{*}{ [125] } \\
\hline & & & & $\begin{array}{l}\text { (-) Short rapamycin treatment for long-term graft } \\
\text { survival }\end{array}$ & \\
\hline & & $\begin{array}{l}\text { CTLA-4Ig and PD-L1 } \\
\text { knock-in }\end{array}$ & $\begin{array}{l}\text { Knock-in human ESCs } \\
\text { transplanted in humanized } \\
\text { mice }\end{array}$ & $\begin{array}{l}(-) \text { Escape from immune surveillance (by grafted } \\
\text { tumorigenic cells and viral infections) }\end{array}$ & [126] \\
\hline & \multirow{5}{*}{ Graft supplementation } & \multirow{2}{*}{ PD-L1 microgels } & \multirow{2}{*}{$\begin{array}{l}\text { Allogeneic mouse islets } \\
\text { co-transplanted with PD-L1 } \\
\text { microgels in mice }\end{array}$} & $\begin{array}{c}\text { (+) Prevents graft rejection, promotes tolerance, confers } \\
\text { local immuno-protective response, off-the-shelf } \\
\text { immunomodulation strategy }\end{array}$ & \multirow[t]{2}{*}{ [127] } \\
\hline & & & & $\begin{array}{l}(-) \text { Some recipients only partial benefit, short low-dose } \\
\text { rapamycin treatment to fully prevent rejection }\end{array}$ & \\
\hline & & \multirow[b]{2}{*}{ MSCs } & \multirow{2}{*}{$\begin{array}{l}\text { Allograft islets in } \\
\text { combination with MSCs } \\
\text { transplanted in mice, rats and } \\
\text { non-human primates }\end{array}$} & $\begin{array}{l}\text { (+) Downregulates pro-inflammatory cytokines, prevents } \\
\text { allograft immune rejection, promotes graft survival }\end{array}$ & \multirow[b]{2}{*}{ [114-117] } \\
\hline & & & & $\begin{array}{c}\text { (-) Logistical and regulatory concerns-clinical } \\
\text { transplantation via hepatic portal vein limits } \\
\text { co-engraftment }\end{array}$ & \\
\hline & & $\begin{array}{l}\text { MSC-derived cell-free } \\
\text { cocktail }\end{array}$ & $\begin{array}{l}\text { Pre-treated mouse islets } \\
\text { transplanted in diabetic mice }\end{array}$ & $\begin{array}{l}\text { (+) Protects from cytokine-mediated cell death in vitro, } \\
\text { improves functional graft survival in vivo }\end{array}$ & [120] \\
\hline
\end{tabular}


Table 3. Cont.

\begin{tabular}{|c|c|c|c|c|c|}
\hline Point of Action & Approach & Intervention & $\begin{array}{l}\text { Species } \\
\text { (Graft to Host) }\end{array}$ & Outcome & Reference \\
\hline \multirow{5}{*}{ Host } & \multirow{2}{*}{ Treg therapy } & \multirow{2}{*}{$\begin{array}{l}\text { Ex vivo expanded polyclonal } \\
\text { or antigen-specific Tregs }\end{array}$} & \multirow{2}{*}{$\begin{array}{l}\text { Tregs injected systemically in } \\
\text { mice and T1D patients }\end{array}$} & $\begin{array}{l}\text { (+) Prolongs islet allograft survival, inhibits alloimmune } \\
\text { response in mice, clinical trials demonstrated feasibility } \\
\text { and safety in human }\end{array}$ & \multirow{2}{*}{ [106-108,128] } \\
\hline & & & & $\begin{array}{l}\text { (-) Poor engraftment, } \\
\text { Treg manufacturing is challenging }\end{array}$ & \\
\hline & $\begin{array}{l}\text { Production of } \\
\text { anti-inflammatory } \\
\text { cytokines }\end{array}$ & $\begin{array}{l}\text { IL-10 secretion by designer } \\
\text { beta cells }\end{array}$ & $\begin{array}{l}\text { Glucose-dependent secretion } \\
\text { of IL-10 by murine beta cells }\end{array}$ & $\begin{array}{l}\text { (+) Protects from pro-inflammatory cytokine-induced cell } \\
\text { death, minimal systemic effects on host immune system, } \\
\text { efficient engineering }\end{array}$ & [111] \\
\hline & \multirow{2}{*}{$\begin{array}{l}\text { Immune-checkpoint } \\
\text { modulation }\end{array}$} & \multirow{2}{*}{$\begin{array}{l}\text { Administration of CTLA-4Ig } \\
\text { and anti CD40L mAbs }\end{array}$} & \multirow{2}{*}{$\begin{array}{l}\text { ESC-PE transplanted in } \\
\text { (humanized) mice }\end{array}$} & $\begin{array}{l}\text { (+) Prevents immune rejection, induces immune } \\
\text { tolerance, prolongs graft survival }\end{array}$ & \multirow[t]{2}{*}{ [129] } \\
\hline & & & & $\begin{array}{l}\text { (-) Testing only possible in immunocompromised } \\
\text { animals (limited to rodents) }\end{array}$ & \\
\hline
\end{tabular}

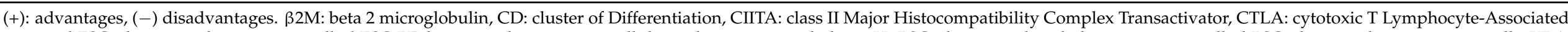

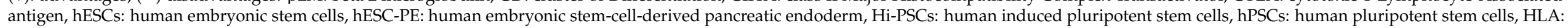

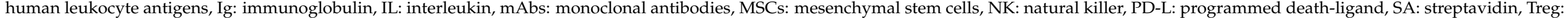
regulatory T-cell. 


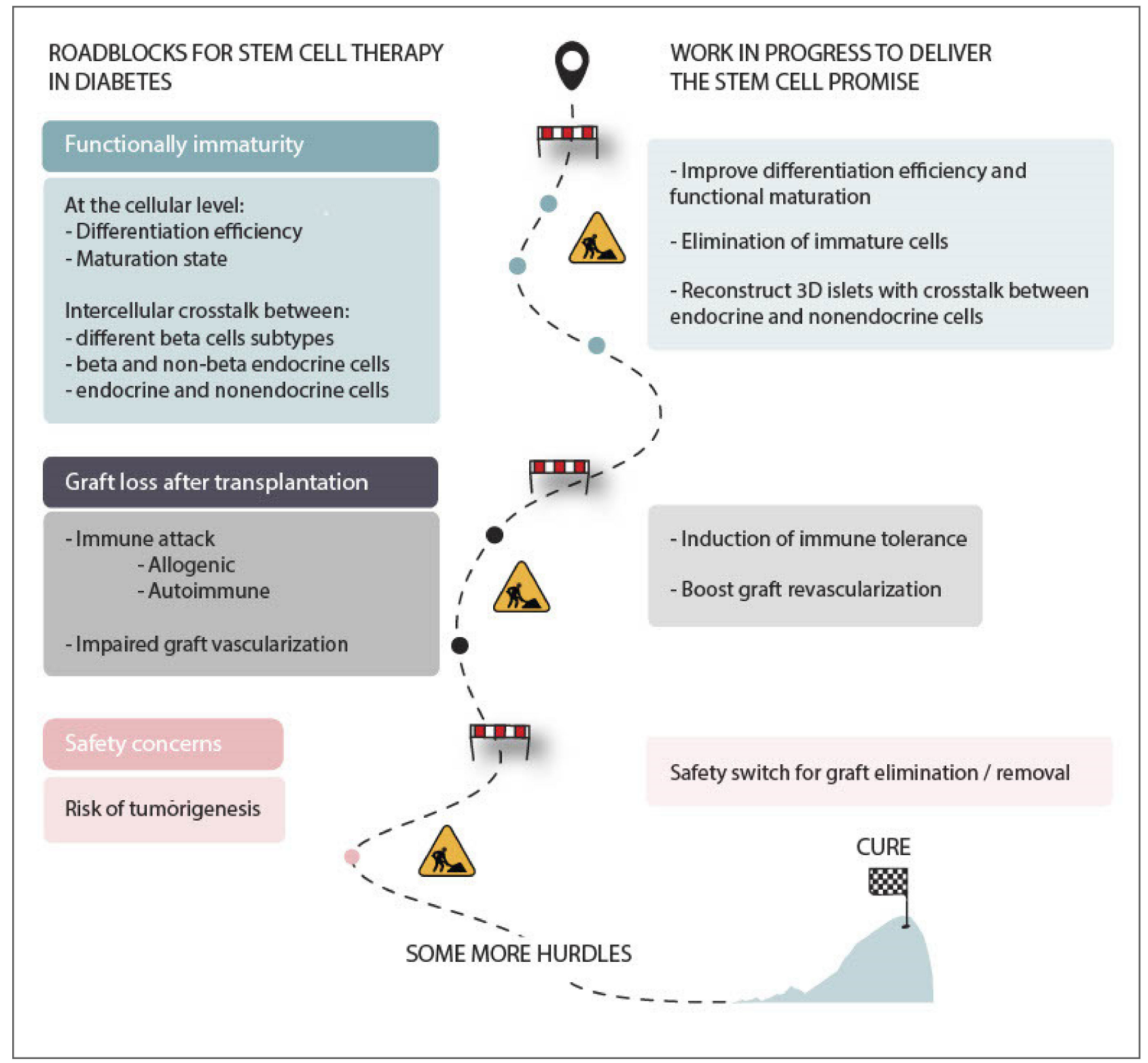

Figure 1. Roadblocks for a functional stem cell-based cure for diabetes. Stem cell-derived beta cells represent a promising alternative beta cell source for transplantation with the potential to cure various forms of diabetes. Nonetheless, major hurdles refrain stem cell-derived beta cells from providing a universal cure for diabetes. The functional maturation of stem cell-derived beta cells remains inferior compared to genuine beta cells, most likely due to the discrepancy of the simplified in vitro differentiation protocols with the complex, dynamic interactions that beta cells encounter in their natural microenvironment throughout development. Generating islet-like clusters containing different endocrine cell types, rather than clusters of only beta-like cells, will likely benefit the functionality of these clusters. Notably, following transplantation, a major donor cell loss occurs mainly due to insufficient graft revascularization and allo-and (auto)immunity. These hurdles can be tackled through delivery of pro-angiogenic factors that boost graft revascularization and by inducing immune tolerance to the graft and countering the underlying autoimmunity. Finally, teratoma formation remains a concern for stem cell therapy to become a therapeutic reality. Strategies to eliminate remaining undifferentiated stem cells need fine-tuning as well as methods to ensure easy graft retrieval in order to warrant the safety of stem cell-derived beta cell grafts. 


\subsection{The Emergence of Encapsulation Devices}

The encapsulation devices have emerged as versatile methods to both enable the removal of transplanted human pluripotent stem cell-derived beta cells and physically shield grafted cells from immune attacks while still allowing for glucose sensing and insulin secretion. In encapsulation strategies, islet cells are embedded in a semipermeable gel-like structure that limits access to immune cells, but still allows for oxygen, nutrient, and hormone transport. Microencapsulation devices are made of biomaterials, such as alginate, while macroencapsulation devices are composed of polymers, such as polycaprolactone or polytetrafluoroethylene [130]. Both of the methods have their advantages and limitations. Microencapsulation devices allow for easier nutrient and oxygen exchange when compared to macroencapsulation devices due to their higher surface area to volume ratio. Whereas macroencapsulation devices are safer, as they are more readily retrievable, and, since a single device can house more cells, membrane parameters, such as pore size and porosity, can be better controlled. The downside here is that this comes at the expense of oxygen and nutrient exchange with individual cells, especially in the core of the graft [131].

\section{Towards a Cure}

\subsection{The Paradigm of Gene-Editing for Monogenic Diabetes}

Gene editing technologies have been developed for almost four decades, since Smithies et al., in 1985, used bacterial restriction endonucleases to create recombinant DNA [132]. Gene-editing endonucleases, such as zinc-finger nucleases, TAL effector nucleases, and CRISPR (clustered regularly interspersed short palindromic repeats)/Cas9 (CRISPR-associated protein 9), are revolutionizing genetic engineering in vitro and in vivo and they reach the efficiencies and precision required for clinical use. CRISPR/Cas9, in particular, is one of the hottest technologies and the favorite designer nuclease, because it does not involve producing target-specific proteins and only requires adjusting a short region of the singleguide RNA to achieve target specificity. This technology provides an innovative resource to generate various types of cells for disease modeling, drug screening, and new therapies in combination with stem cell technology.

Monogenic forms of diabetes are caused by mutations in genes that are involved in beta cell development, function, and survival $[50,133]$. Several groups have compared monogenic diabetes patients' and healthy controls' iPSC-derived beta cells. iPSCs from patients with an HNF4A mutation, causing autosomal dominant diabetes, differentiated similarly to healthy control iPSCs, and the iPSC-beta cells showed no obvious quantitative proteome differences [134]. Autosomal dominant HNF1B mutations result in diabetes and pancreatic hypoplasia [135]. Teo et al. showed that the expression of the pancreatic progenitor markers PDX1, FOXA2, and GATA4/6 is increased in HNF1B mutant cells, while PAX6 is decreased [136]. The heterozygous or homozygous HNF1A knockout in ESCs by CRISPR/Cas9 dose-dependently altered endocrine hormone expression, increased alpha cell gene expression, and impacted beta cell metabolism and insulin secretion [137]. McGrath et al. used CRISPR/Cas9 in ESCs to disrupt NEUROG3, which is associated with permanent neonatal diabetes mellitus [138-141], and showed that NEUROG3 is required for human pancreatic endocrine cell development [142]. Interestingly, Saarimäki-Vire et al. demonstrated that activating STAT3 mutations, a cause of neonatal diabetes associated with beta cell autoimmunity [143], cause premature endocrine differentiation of patient's iPSCs through the direct premature induction of NEUROG3 expression. The differentiation phenotype was reversed when the STAT3 mutation was corrected with CRISPR/Cas9 [144]. Activating mutations in KCNJ11, the pore-forming subunit of the $\mathrm{K}_{\mathrm{ATP}}$ channel, also cause neonatal diabetes [145-147]. The biallelic KCNJ11 mutation in human ESCs impairs insulin secretion that is induced by various stimuli, such as glucose, $\mathrm{KCl}$, and forskolin, because of absent $\mathrm{K}_{\text {ATP }}$ channel activity [148]. Heterozygous mutations in GATA6 [149] and its sister gene GATA4 [150] can cause neonatal diabetes through pancreatic agenesis. These transcription factors were shown to be essential for pancreatic development while using patient's iPSCs and iPSCs that are corrected by CRISPR/Cas9 [151,152]. Dominant insulin gene mu- 
tations are a common cause of neonatal diabetes $[153,154]$. These mutations induce insulin protein misfolding, endoplasmic reticulum (ER) stress, and activate the unfolded protein response, which leads to beta cell failure [155,156]. Balboa et al. generated iPSCs from patients with the Akita insulin gene mutation and corrected it using CRISPR/Cas9 [157]. The transplantation of insulin gene mutant beta-like cells into mice resulted in low insulin secretion and the induction of ER stress markers when compared to transplanted corrected beta-like cells. De Franco et al. discovered a neonatal type of diabetes caused by recessive YIPF5 mutations [158]. They showed increased in vitro sensitivity of patients' iPSC-derived beta cells to ER stress, which is caused by impaired proinsulin trafficking from the ER to the Golgi, and impaired in vivo function of ESCs edited to express the patients' mutation.

Patients with Wolfram syndrome, an autosomal recessive disorder that is caused by WFS1 mutations, develop childhood diabetes as a result of beta cell ER stress (reviewed in $[159,160])$. Following CRISPR/Cas9 correction of WFS1 mutations in patients' iPSCs, iPSC-beta cells showed dynamic glucose-stimulated insulin secretion and reversed preexisting streptozotocin-induced diabetes after transplantation into mice [161]. Finally, Friedreich ataxia is an autosomal recessive neurodegenerative disease that is associated with a high risk of developing diabetes. It is caused by intronic GAA trinucleotide repeat expansions in the frataxin-encoding FXN gene that reduces frataxin transcription and causes mitochondrial dysfunction [162-165]. GLP-1 analogs improve mitochondrial function in frataxin-deficient cells and induce frataxin expression in Friedreich ataxia patients' iPSC-derived neurons and beta-like cells [166]. Taken together, this growing body of evidence shows that the gene editing of iPSCs from patients with monogenic diabetes allows for generating functional beta cells with the potential to provide a personalized cell source for cell replacement therapy (Figure 2).

\subsection{Where Do the Clinical Trials in T1D Stand?}

Hitherto four clinical trials in T1D with stem cell-derived pancreatic cells have been registered, all being initiated by the company ViaCyte. In 2014, the first trial (NCT02239354) was posted on the clinicaltrials.gov platform as a "Prospective, Multicenter, Open-Label, First-in-Human Phase 1/2 Study With Two Cohorts to Evaluate the Safety, Tolerability, and Efficacy of Various Doses of VC-01 ${ }^{\mathrm{TM}}$ Combination Product in Subjects With Type 1 Diabetes Mellitus". This VC-01 ${ }^{\mathrm{TM}}$ combination product consists of a biological product-i.e., pancreatic progenitor cells differentiated from human ESCs (PEC-01) - and a macroencapsulation device. In 2016, a follow-up prospective trial "A One-Year, Multicenter, Observational, Follow-up Safety Study in Subjects Previously Implanted With VC-01 ${ }^{\mathrm{TM}}$ Combination Product" was posted in order to document the incidence of adverse events that were reported during the study with the VC-01 device. With the estimated final completion dates of NCT02239354 (January 2021) and NCT02939118 (November 2021) approaching, some preliminary results of 19 subjects that have been implanted and evaluated have been reported [14]. These results indicate that the approach is safe and well tolerated with relatively minor adverse events, but, while protection from immune rejection was reported, inconsistent long term graft survival was observed, which is attributed to a foreign body reaction to the device component for which further optimization was due. In 2017, the company launched two more trials. First, NCT03162926 "A Safety and Tolerability Study of VC-02 ${ }^{\mathrm{TM}}$ Combination Product in Subjects With Type 1 Diabetes Mellitus", in which their combination product $\mathrm{VC}-02^{\mathrm{TM}}$ is tested of which the device component is changed from a semi-permeable encapsulation device-that prevents immune cells and blood vessels to enter the biological compartment-to an encapsulation device that does allow for the entry of immune cells and blood vessels (final completion in February 2018). Second, NCT03163511 "A Safety, Tolerability, and Efficacy Study of VC-02 ${ }^{\mathrm{TM}}$ Combination Product in Subjects With Type 1 Diabetes Mellitus and Hypoglycemia Unawareness", in which the same combination product is investigated, specifically in patients with hypoglycemia unawareness or significant glycemic lability (estimated completion in March 2023). 


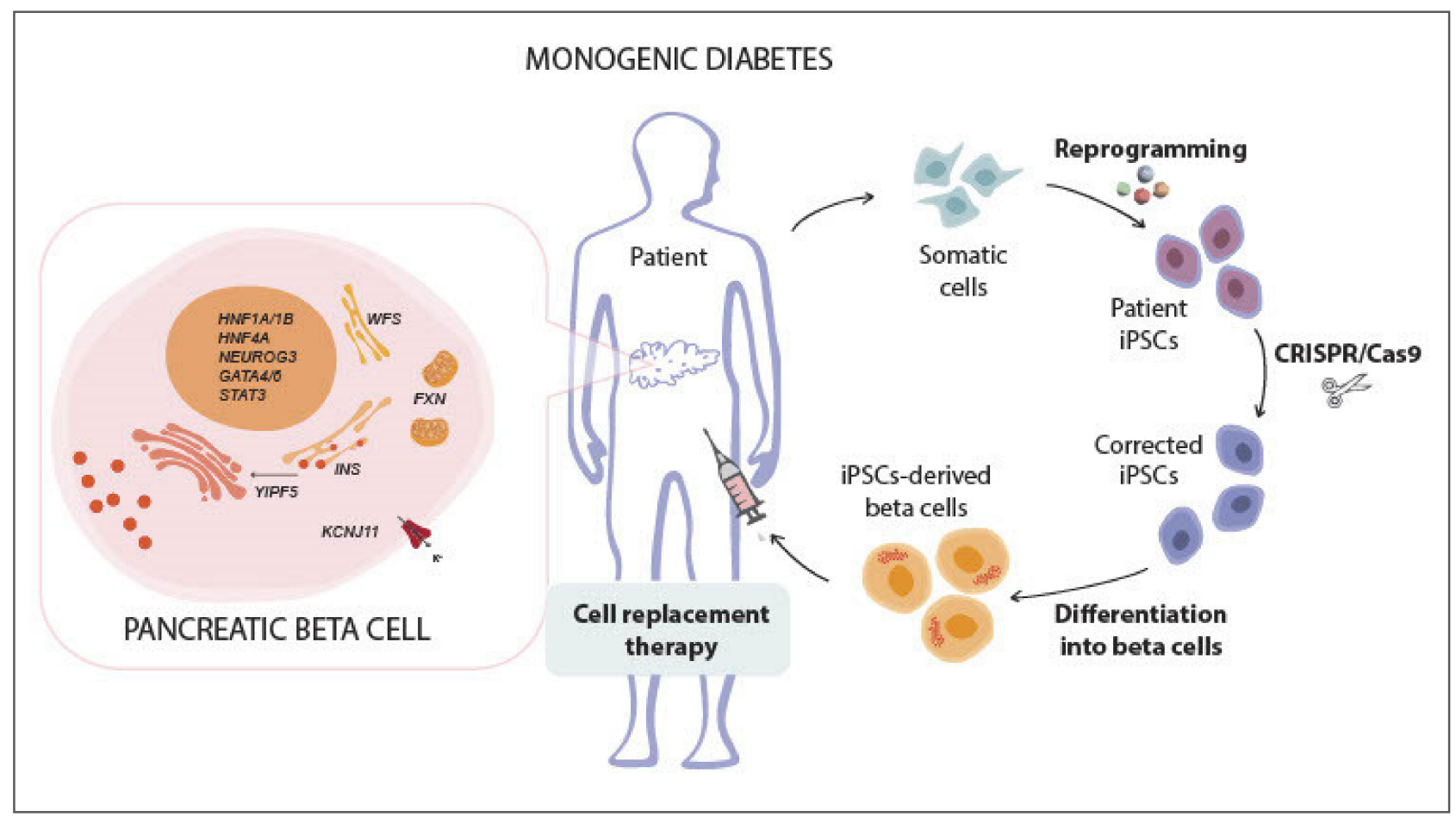

Figure 2. The curative promise of engineered human iPSC-derived beta cells for monogenic diabetes. Monogenic forms of diabetes are caused by mutations in genes critical for beta cell development, function and survival. More specifically, mutations within the HNF4A, HNF1A/1B, NEUROG3, GATA4/6, and STAT3 genes impair beta cell development or pancreatic endocrine development and cause maturity-onset diabetes of the young and neonatal diabetes. Mutations within the KCNJ11 gene result in dysfunctional $\mathrm{K}_{\mathrm{ATP}}$-channels, which results in impaired insulin secretion. Furthermore, mutations within the YIPF5 gene are responsible for impaired proinsulin trafficking from the endoplasmic reticulum to the Golgi apparatus, giving rise to endoplasmic reticulum stress. Interestingly, other rare disorders, such as Friedreich ataxia and the Wolfram syndrome exist that are accompanied by diabetes. Friedreich ataxia is associated with a reduced expression of the FXN gene, which causes mitochondrial dysfunction, while Wolfram syndrome is characterized by a dysfunctional WFS1 gene, which leads to endoplasmic reticulum stress. Since these rare forms of diabetes are usually triggered by a single genetic mutation, it becomes theoretically possible to correct them in patient-derived iPSCs while using CRISPR/Cas9 before their differentiation into healthy beta cells which can be transplanted back into the patient.

Although these trials pave the way for a future functional cure for diabetes, it remains to be evaluated whether the use of pancreatic progenitor cells is the best path if our goal is the full replacement of the functional beta cell mass in patients with diabetes. In order to obtain a true cure and to eliminate the daily burden of diabetes care, the grafted cells will have to reach — at least upon engraftment—full functional maturity in addition to being sufficiently numerous to be able to tightly regulate glucose homeostasis.

\section{Perspectives}

Although current human pluripotent stem cell differentiation protocols succeed in generating beta-like cells that share many phenotypical and functional properties with bona fide beta cells, reaching full functional maturation remains challenging, as: (i) adult beta cells are heterogenous and (ii) current differentiation protocols are based on simplified mimicry of the dynamic and complex interactions of beta cells with other (non)endocrine cells in their native microenvironment. This intercellular communication is likely key to reach, or at least maintain, full beta cell maturity in all of its complexity and heterogeneity. 
Author Contributions: S.B. and T.S. wrote the original draft. W.S. and M.C. supervised the writing of the manuscript. A.V.M., N.D.L., Y.H. and H.H. assisted on critical revision of the article for important intellectual content. All authors have given final approval. All authors have read and agreed to the published version of the manuscript.

Funding: This work was supported by the Universitaire Stichting van België (WA-0337) and Wetenschappelijk Fonds Willy Gepts of the UZ Brussel (WFWG20-17). The authors received no specific funding for this work. SB holds a PhD fellowship strategic basic research from the Research Foundation Flanders (File number: 81311). TS holds a Marie Skłodowska-Curie Actions Fellowship from the European Union's Horizon 2020 research and innovation programme under the Marie SkłodowskaCurie grant agreement No 801505. WS holds a senior clinical investigator grant from the Research Foundation Flanders (File number: 77833). Work in the Cnop lab is supported by grants from the Fonds Erasme, Fondation ULB, the Fonds National de la Recherche Scientifique (FNRS), the Brussels Capital Region Innoviris project DiaType and the Francophone Foundation for Diabetes Research (FFRD that is sponsored by the French Diabetes Federation, Abbott, Eli Lilly, Merck Sharp \& Dohme and Novo Nordisk), and by the Innovative Medicines Initiative 2 Joint Undertaking under grant agreement 115797 (INNODIA) and 945268 (INNODIA HARVEST). This Joint Undertaking receives support from the Union's Horizon 2020 research and innovation programme and the European Federation of Pharmaceutical Industries and Associations, JDRF, and the Leona M. and Harry B. Helmsley Charitable Trust.

Institutional Review Board Statement: Not applicable.

Informed Consent Statement: Not applicable.

Data Availability Statement: Not applicable.

Conflicts of Interest: The authors declare no conflict of interest.

\section{References}

1. International Diabetes Federation. IDF Diabetes Atlas, 9th ed.; International Diabetes Federation: Brussels, Belgium, 2019; Available online: https: / / www.diabetesatlas.org (accessed on 1 November 2020).

2. Herold, K.C.; Vignali, D.A.A.; Cooke, A.; Bluestone, J.A. Type 1 diabetes: Translating mechanistic observations into effective clinical outcomes. Nat. Rev. Immunol. 2013, 13, 243-256. [CrossRef] [PubMed]

3. Nolan, C.J.; Damm, P.; Prentki, M. Type 2 diabetes across generations: From pathophysiology to prevention and management. Lancet 2011, 378, 169-181. [CrossRef]

4. Yang, Y.; Chan, L. Monogenic diabetes: What it teaches us on the common forms of type 1 and type 2 diabetes. Endocr. Rev. 2016, 37, 190-222. [CrossRef] [PubMed]

5. Gamble, A.; Pepper, A.R.; Bruni, A.; Shapiro, A.M.J. The journey of islet cell transplantation and future development. Islets 2018, 10, 80-94. [CrossRef] [PubMed]

6. Shapiro, A.J.; Lakey, J.R.; Ryan, E.A.; Korbutt, G.S.; Toth, E.; Warnock, G.L.; Kneteman, N.M.; Rajotte, R.V. Islet transplantation in seven patients with type 1 diabetes mellitus using a glucocorticoid-free immunosuppressive regimen. N. Engl. J. Med. 2000, 343, 230-238. [CrossRef] [PubMed]

7. Fiorina, P.; Shapiro, A.M.J.; Ricordi, C.; Secchi, A. The clinical impact of islet transplantation. Am. J. Transplant. 2008, 8, 1990-1997. [CrossRef]

8. Thompson, D.M.; Meloche, M.; Ao, Z.; Paty, B.; Keown, P.; Shapiro, R.J.; Ho, S.; Worsley, D.; Fung, M.; Meneilly, G.; et al. Reduced progression of diabetic microvascular complications with islet cell transplantation compared with intensive medical therapy. Transplantation 2011, 91, 373-378. [CrossRef]

9. Warnock, G.L.; Thompson, D.M.; Meloche, R.M.; Shapiro, R.J.; Ao, Z.; Keown, P.; Johnson, J.D.; Verchere, C.B.; Partovi, N.; Begg, I.S.; et al. A multi-year analysis of islet transplantation compared with intensive medical therapy on progression of complications in type 1 diabetes. Transplantation 2008, 86, 1762-1766. [CrossRef]

10. Staels, W.; De Groef, S.; Heremans, Y.; Coppens, V.; Van Gassen, N.; Leuckx, G.; Van De Casteele, M.; Van Riet, I.; Luttun, A.; Heimberg, H.; et al. Accessory cells for $\beta$-cell transplantation. Diabetes Obes. Metab. 2015, 18, 115-124. [CrossRef]

11. Carlsson, P.-O.; Palm, F.; Mattsson, G. Low revascularization of experimentally transplanted human pancreatic islets. J. Clin. Endocrinol. Metab. 2002, 87, 5418-5423. [CrossRef]

12. Davalli, A.M.; Scaglia, L.; Zangen, D.H.; Hollister, J.; Bonner-Weir, S.; Weir, G.C. Vulnerability of islets in the immediate posttransplantation period: Dynamic changes in structure and function. Diabetes 1996, 45, 1161-1167. [CrossRef] [PubMed]

13. Ryan, E.A.; Paty, B.W.; Senior, P.A.; Shapiro, A.M.J. Risks and side effects of islet transplantation. Curr. Diabetes Rep. 2004, 4, 304-309. [CrossRef] [PubMed] 
14. Henry, R.R.; Pettus, J.; Wilensky, J.; Shapiro, A.M.J.; Senior, P.A.; Roep, B.; Wang, R.; Kroon, E.J.; Scott, M.; D'Amour, K.; et al. Initial clinical evaluation of VC- $01^{\mathrm{TM}}$ combination product-A stem cell-derived islet replacement for type 1 diabetes (T1D). Diabetes 2018, 67, 138. [CrossRef]

15. Nicholls, D.G. The pancreatic $\beta$-cell: A bioenergetic perspective. Physiol. Rev. 2016, 96, 1385-1447. [CrossRef]

16. Rorsman, P.; Ashcroft, F.M. Pancreatic $\beta$-cell electrical activity and insulin secretion: Of mice and men. Physiol. Rev. 2018, 98, 117-214. [CrossRef]

17. Lacy, P.E.; Walker, M.M.; Fink, C.J. Perifusion of isolated rat islets in vitro: Participation of the microtubular system in the biphasic release of insulin. Diabetes 1972, 21, 987-998. [CrossRef]

18. Curry, D.L.; Bennett, L.L.; Grodsky, G.M. Dynamics of insulin secretion by the perfused rat pancreas. Endocrinology 1968, 83, 572-584. [CrossRef]

19. Gembal, M.; Detimary, P.; Gilon, P.; Gao, Z.Y.; Henquin, J.C. Mechanisms by which glucose can control insulin release independently from its action on adenosine triphosphate-sensitive K+ channels in mouse B cells. J. Clin. Investig. 1993, 91, 871-880. [CrossRef]

20. Kang, H.S.; Kim, Y.-S.; ZeRuth, G.; Beak, J.Y.; Gerrish, K.; Kilic, G.; Sosa-Pineda, B.; Jensen, J.L.; Foley, J.F.; Jetten, A.M. Transcription factor Glis3, a novel critical player in the regulation of pancreatic $\beta$-cell development and insulin gene expression. Mol. Cell. Biol. 2009, 29, 6366-6379. [CrossRef]

21. Zhu, Y.; Liu, Q.; Zhou, Z.; Ikeda, Y. PDX1, Neurogenin-3, and MAFA: Critical transcription regulators for beta cell development and regeneration. Stem Cell Res. Ther. 2017, 8, 1-7. [CrossRef]

22. Gu, C.; Stein, G.H.; Pan, N.; Goebbels, S.; Hörnberg, H.; Nave, K.-A.; Herrera, P.L.; White, P.; Kaestner, K.H.; Sussel, L.; et al. Pancreatic $\beta$ cells require NeuroD to achieve and maintain functional maturity. Cell Metab. 2010, 11, 298-310. [CrossRef] [PubMed]

23. Taylor, B.L.; Liu, F.-F.; Sander, M. Nkx6.1 is essential for maintaining the functional state of pancreatic beta cells. Cell Rep. 2013, 4, 1262-1275. [CrossRef] [PubMed]

24. Gosmain, Y.; Katz, L.S.; Masson, M.H.; Cheyssac, C.; Poisson, C.; Philippe, J. Pax6 is crucial for $\beta$-cell function, insulin biosynthesis, and glucose-induced insulin secretion. Mol. Endocrinol. 2012, 26, 696-709. [CrossRef] [PubMed]

25. Gao, T.; McKenna, B.; Li, C.; Reichert, M.; Nguyen, J.; Singh, T.; Yang, C.; Pannikar, A.; Doliba, N.M.; Zhang, T.; et al. Pdx1 maintains $\beta$ cell identity and function by repressing an $\alpha$ cell program. Cell Metab. 2014, 19, 259-271. [CrossRef] [PubMed]

26. Velazco-Cruz, L.; Goedegebuure, M.M.; Maxwell, K.G.; Augsornworawat, P.; Hogrebe, N.J.; Millman, J.R. SIX2 regulates human $\beta$ cell differentiation from stem cells and functional maturation in vitro. Cell Rep. 2020, 31, 107687. [CrossRef] [PubMed]

27. Van Der Meulen, T.; Donaldson, C.J.; Cáceres, E.; Hunter, A.E.; Cowing-Zitron, C.; Pound, L.D.; Adams, M.W.; Zembrzycki, A.; Grove, K.L.; Huising, M.O. Urocortin3 mediates somatostatin-dependent negative feedback control of insulin secretion. Nat. Med. 2015, 21, 769-776. [CrossRef] [PubMed]

28. Blum, B.; Hrvatin, S.; Schuetz, C.; Bonal, C.; Rezaniaand, A.; Melton, D.A. Functional beta-cell maturation is marked by an increased glucose threshold and by expression of urocortin 3. Nat. Biotechnol. 2012, 30, 261-264. [CrossRef] [PubMed]

29. Lemaire, K.; Thorrez, L.; Schuit, F. Disallowed and allowed gene expression: Two faces of mature islet beta cells. Annu. Rev. Nutr. 2016, 36, 45-71. [CrossRef]

30. Ebrahimi, A.; Hollister-Lock, J.; Sullivan, B.A.; Tsuchida, R.; Bonner-Weir, S.; Weir, G.C. Beta cell identity changes with mild hyperglycemia: Implications for function, growth, and vulnerability. Mol. Metab. 2020, 35, 100959. [CrossRef]

31. Scaglia, L.; Cahill, C.J.; Finegood, D.T.; Bonner-Weir, S. Apoptosis participates in the remodeling of the endocrine pancreas in the neonatal rat. Endocrinology 1997, 138, 1736-1741. [CrossRef]

32. Reers, C.; Erbel, S.; Esposito, I.; Schmied, B.; Büchler, M.W.; Nawroth, P.P.; Ritzel, R.A. Impaired islet turnover in human donor pancreata with aging. Eur. J. Endocrinol. 2009, 160, 185-191. [CrossRef] [PubMed]

33. Perl, S.; Kushner, J.A.; Buchholz, B.A.; Meeker, A.K.; Stein, G.M.; Hsieh, M.; Kirby, M.; Pechhold, S.; Liu, E.H.; Harlan, D.M.; et al. Significant human $\beta$-cell turnover is limited to the first three decades of life as determined by in vivo thymidine analog incorporation and radiocarbon dating. J. Clin. Endocrinol. Metab. 2010, 95, E234-E239. [CrossRef] [PubMed]

34. Butler, A.E.; Janson, J.; Bonner-Weir, S.; Ritzel, R.A.; Rizza, R.A.; Butler, P.C. $\beta$-Cell deficit and increased $\beta$-cell apoptosis in humans with type 2 diabetes. Diabetes 2003, 52, 102-110. [CrossRef] [PubMed]

35. Cnop, M.; Igoillo-Esteve, M.; Hughes, S.; Walker, J.N.; Cnop, I.; Clark, A. Longevity of human islet $\alpha$ - and $\beta$-cells. Diabetes Obes. Metab. 2011, 13, 39-46. [CrossRef] [PubMed]

36. Cnop, M.; Hughes, S.J.; Igoillo-Esteve, M.; Hoppa, M.B.; Sayyed, F.; van de Laar, L.; Gunter, J.H.; de Koning, E.J.P.; Walls, G.V.; Gray, D.W.G.; et al. The long lifespan and low turnover of human islet beta cells estimated by mathematical modelling of lipofuscin accumulation. Diabetologia 2009, 53, 321. [CrossRef]

37. Pipeleers, D.G. Heterogeneity in pancreatic $\beta$-cell population. Diabetes 1992, 41, 777-781. [CrossRef]

38. Van Schravendijk, C.F.; Kiekens, R.; Pipeleers, D.G. Pancreatic beta cell heterogeneity in glucose-induced insulin secretion. J. Biol. Chem. 1992, 267, 21344-21348. [CrossRef]

39. Heimberg, H.; De Vos, A.; Vandercammen, A.; Van Schaftingen, E.; Pipeleers, D.; Schuit, F. Heterogeneity in glucose sensitivity among pancreatic beta-cells is correlated to differences in glucose phosphorylation rather than glucose transport. EMBO J. 1993, 12, 2873-2879. [CrossRef]

40. Johnston, N.R.; Mitchell, R.K.; Haythorne, E.; Pessoa, M.P.; Semplici, F.; Ferrer, J.; Piemonti, L.; Marchetti, P.; Bugliani, M.; Bosco, D.; et al. Beta cell hubs dictate pancreatic islet responses to glucose. Cell Metab. 2016, 24, 389-401. [CrossRef] 
41. Bader, E.; Migliorini, A.; Gegg, M.; Moruzzi, N.; Gerdes, J.; Roscioni, S.S.; Bakhti, M.; Brandl, E.; Irmler, M.; Beckers, J.; et al. Identification of proliferative and mature $\beta$-cells in the islets of Langerhans. Nature 2016, 535, 430-434. [CrossRef]

42. Van Der Meulen, T.; Mawla, A.M.; DiGruccio, M.R.; Adams, M.W.; Nies, V.; Dólleman, S.; Liu, S.; Ackermann, A.M.; Cáceres, E.; Hunter, A.E.; et al. Virgin beta cells persist throughout life at a neogenic niche within pancreatic islets. Cell Metab. 2017, 25, 911-926.e6. [CrossRef]

43. Weissman, I.L.; Anderson, D.J.; Gage, F. Stem and progenitor cells: Origins, phenotypes, lineage commitments, and transdifferentiations. Annu. Rev. Cell Dev. Biol. 2001, 17, 387-403. [CrossRef] [PubMed]

44. Evans, M.J.; Kaufman, M.H. Establishment in culture of pluripotential cells from mouse embryos. Nat. Cell Biol. 1981, 292, 154-156. [CrossRef] [PubMed]

45. Thomson, J.A.; Itskovitz-Eldor, J.; Shapiro, S.S.; Waknitz, M.A.; Swiergiel, J.J.; Marshall, V.S.; Jones, J.M. Embryonic stem cell lines derived from human blastocysts. Science 1998, 282, 1145-1147. [CrossRef] [PubMed]

46. Takahashi, K.; Tanabe, K.; Ohnuki, M.; Narita, M.; Ichisaka, T.; Tomoda, K.; Yamanaka, S. Induction of pluripotent stem cells from adult human fibroblasts by defined factors. Cell 2007, 131, 861-872. [CrossRef] [PubMed]

47. D'Amour, K.A.; Agulnick, A.D.; Eliazer, S.; Kelly, O.G.; Kroon, E.; Baetge, E.E. Efficient differentiation of human embryonic stem cells to definitive endoderm. Nat. Biotechnol. 2005, 23, 1534-1541. [CrossRef] [PubMed]

48. D'Amour, K.A.; Bang, A.G.; Eliazer, S.; Kelly, O.G.; Agulnick, A.D.; Smart, N.G.; Moorman, M.A.; Kroon, E.; Carpenter, M.K.; Baetge, E.E. Production of pancreatic hormone-expressing endocrine cells from human embryonic stem cells. Nat. Biotechnol. 2006, 24, 1392-1401. [CrossRef]

49. Riedel, M.J.; Asadi, A.; Wang, R.; Ao, Z.; Warnock, G.L.; Kieffer, T.J. Immunohistochemical characterisation of cells co-producing insulin and glucagon in the developing human pancreas. Diabetologia 2011, 55, 372-381. [CrossRef]

50. Jennings, R.E.; Scharfmann, R.; Staels, W. Transcription factors that shape the mammalian pancreas. Diabetologia 2020, 63, 1974-1980. [CrossRef]

51. Russ, H.A.; Parent, A.V.; Ringler, J.J.; Hennings, T.G.; Nair, G.G.; Shveygert, M.; Guo, T.; Puri, S.; Haataja, L.; Cirulli, V.; et al. Controlled induction of human pancreatic progenitors produces functional beta-like cells in vitro. EMBO J. 2015, 34, 1759-1772. [CrossRef]

52. Pagliuca, F.W.; Millman, J.R.; Gürtler, M.; Segel, M.; van Dervort, A.; Ryu, J.H.; Peterson, Q.P.; Greiner, D.; Melton, D.A. Generation of functional human pancreatic $\beta$ cells in vitro. Cell 2014, 159, 428-439. [CrossRef] [PubMed]

53. Rezania, A.; Bruin, J.E.; Arora, P.; Rubin, A.; Batushansky, I.; Asadi, A.; O’Dwyer, S.; Quiskamp, N.; Mojibian, M.; Albrecht, T.; et al. Reversal of diabetes with insulin-producing cells derived in vitro from human pluripotent stem cells. Nat. Biotechnol. 2014, 32, 1121-1133. [CrossRef] [PubMed]

54. Ghazizadeh, Z.; Kao, D.-I.; Amin, S.; Cook, B.; Rao, S.; Zhou, T.; Zhang, T.; Xiang, Z.; Kenyon, R.; Kaymakcalan, O.; et al. ROCKII inhibition promotes the maturation of human pancreatic beta-like cells. Nat. Commun. 2017, 8, 298. [CrossRef] [PubMed]

55. Zhu, S.; Russ, H.A.; Wang, X.; Zhang, M.; Ma, T.; Xu, T.; Tang, S.; Hebrok, M.; Ding, S. Human pancreatic beta-like cells converted from fibroblasts. Nat. Commun. 2016, 7, 10080. [CrossRef] [PubMed]

56. Millman, J.R.; Xie, C.; Van Dervort, A.; Gürtler, M.; Pagliuca, F.W.; Melton, D.A. Generation of stem cell-derived $\beta$-cells from patients with type 1 diabetes. Nat. Commun. 2016, 7, 11463. [CrossRef] [PubMed]

57. Nair, G.G.; Liu, J.S.; Russ, H.A.; Tran, S.; Saxton, M.S.; Chen, R.; Juang, C.; Li, M.-L.; Nguyen, V.Q.; Giacometti, S.; et al. Recapitulating endocrine cell clustering in culture promotes maturation of human stem-cell-derived $\beta$ cells. Nat. Cell Biol. 2019, 21, 263-274. [CrossRef]

58. Velazco-Cruz, L.; Song, J.; Maxwell, K.G.; Goedegebuure, M.M.; Augsornworawat, P.; Hogrebe, N.J.; Millman, J.R. Acquisition of dynamic function in human stem cell-derived $\beta$ cells. Stem Cell Rep. 2019, 12, 351-365. [CrossRef]

59. Gao, Y.; Zhang, R.; Dai, S.; Zhang, X.; Li, X.; Zhu, Z. Role of TGF- $\beta$ /smad pathway in the transcription of pancreas-specific genes during beta cell differentiation. Front. Cell Dev. Biol. 2019, 7, 351. [CrossRef]

60. Lin, H.-M.; Lee, J.-H.; Yadav, H.; Kamaraju, A.K.; Liu, E.; Zhigang, D.; Vieira, A.; Kim, S.-J.; Collins, H.W.; Matschinsky, F.M.; et al. Transforming growth factor- $\beta / \operatorname{smad} 3$ signaling regulates insulin gene transcription and pancreatic islet $\beta$-cell function. J. Biol. Chem. 2009, 284, 12246-12257. [CrossRef]

61. Totsuka, Y.; Tabuchi, M.; Kojima, I.; Eto, Y.; Shibai, H.; Ogata, E. Stimulation of insulin secretion by transforming growth factor- $\beta$. Biochem. Biophys. Res. Commun. 1989, 158, 1060-1065. [CrossRef]

62. Nomura, M.; Zhu, H.-L.; Wang, L.; Morinaga, H.; Takayanagi, R.; Teramoto, N. SMAD2 disruption in mouse pancreatic beta cells leads to islet hyperplasia and impaired insulin secretion due to the attenuation of ATP-sensitive K+ channel activity. Diabetologia 2013, 57, 157-166. [CrossRef] [PubMed]

63. Yoshihara, E.; O'Connor, C.; Gasser, E.; Wei, Z.; Oh, T.G.; Tseng, T.W.; Wang, D.; Cayabyab, F.; Dai, Y.; Yu, R.T.; et al. Immuneevasive human islet-like organoids ameliorate diabetes. Nature 2020, 586, 606-611. [CrossRef] [PubMed]

64. Nostro, M.C.; Sarangi, F.; Yang, C.; Holland, A.M.; Elefanty, A.G.; Stanley, E.G.; Greiner, D.L.; Keller, G. Efficient generation of NKX6-1+ pancreatic progenitors from multiple human pluripotent stem cell lines. Stem Cell Rep. 2015, 4, 591-604. [CrossRef] [PubMed]

65. Li, X.; Yang, K.Y.; Chan, V.W.; Leung, K.T.; Zhang, X.-B.; Wong, A.S.; Chong, C.C.; Wang, C.C.; Ku, M.; Lui, K.O. Single-cell RNA-seq reveals that CD9 is a negative marker of glucose-responsive pancreatic $\beta$-like cells derived from human pluripotent stem cells. Stem Cell Rep. 2020, 15, 1111-1126. [CrossRef] [PubMed]

66. Veres, A.; Faust, A.L.; Bushnell, H.L.; Engquist, E.N.; Kenty, J.H.-R.; Harb, G.; Poh, Y.-C.; Sintov, E.; Gürtler, M.; Pagliuca, F.W.; et al. Charting cellular identity during human in vitro $\beta$-cell differentiation. Nature 2019, 569, 368-373. [CrossRef] 
67. Brissova, M.; Haliyur, R.; Saunders, D.; Shrestha, S.; Dai, C.; Blodgett, D.M.; Bottino, R.; Campbell-Thompson, M.; Aramandla, R.; Poffenberger, G.; et al. $\alpha$ cell function and gene expression are compromised in type 1 diabetes. Cell Rep. 2018, 22, 2667-2676. [CrossRef]

68. Unger, R.H.; Cherrington, A.D. Glucagonocentric restructuring of diabetes: A pathophysiologic and therapeutic makeover. J. Clin. Investig. 2012, 122, 4-12. [CrossRef]

69. Siafarikas, A.; Johnston, R.J.; Bulsara, M.K.; O’Leary, P.; Jones, T.W.; Davis, E.A. Early loss of the glucagon response to hypoglycemia in adolescents with type 1 diabetes. Diabetes Care 2012, 35, 1757-1762. [CrossRef]

70. Rezania, A.; Bruin, J.E.; Riedel, M.J.; Mojibian, M.; Asadi, A.; Xu, J.; Gauvin, R.; Narayan, K.; Karanu, F.; O’Neil, J.J.; et al. Maturation of human embryonic stem cell-derived pancreatic progenitors into functional islets capable of treating pre-existing diabetes in mice. Diabetes 2012, 61, 2016-2029. [CrossRef]

71. Schulz, T.C.; Young, H.Y.; Agulnick, A.D.; Babin, M.J.; Baetge, E.E.; Bang, A.G.; Bhoumik, A.; Cepa, I.; Cesario, R.M.; Haakmeester, C.; et al. A scalable system for production of functional pancreatic progenitors from human embryonic stem cells. PLoS ONE 2012, 7, e37004. [CrossRef]

72. Hrvatin, S.; O’Donnell, C.W.; Deng, F.; Millman, J.R.; Pagliuca, F.W.; DiIorio, P.; Rezania, A.; Gifford, D.K.; Melton, D.A. Differentiated human stem cells resemble fetal, not adult, $\beta$ cells. Proc. Natl. Acad. Sci. USA 2014, 111, 3038-3043. [CrossRef] [PubMed]

73. Rezania, A.; Riedel, M.J.; Wideman, R.D.; Karanu, F.; Ao, Z.; Warnock, G.L.; Kieffer, T.J. Production of functional glucagonsecreting $\alpha$-cells from human embryonic stem cells. Diabetes 2010, 60, 239-247. [CrossRef] [PubMed]

74. Peterson, Q.P.; Veres, A.; Chen, L.; Slama, M.Q.; Kenty, J.H.; Hassoun, S.; Brown, M.R.; Dou, H.; Duffy, C.D.; Zhou, Q.; et al. A method for the generation of human stem cell-derived alpha cells. Nat. Commun. 2020, 11, 2241. [CrossRef] [PubMed]

75. Ravier, M.A.; Güldenagel, M.; Charollais, A.; Gjinovci, A.; Caille, D.; Söhl, G.; Wollheim, C.B.; Willecke, K.; Henquin, J.-C.; Meda, P. Loss of Connexin 36 channels alters $\beta$-cell coupling, islet synchronization of glucose-induced $\mathrm{Ca}^{2+}$ and insulin oscillations, and basal insulin release. Diabetes 2005, 54, 1798-1807. [CrossRef] [PubMed]

76. Charollais, A.; Gjinovci, A.; Huarte, J.; Bauquis, J.; Nadal, A.; Martín, F.; Andreu, E.; Sánchez-Andrés, J.V.; Calabrese, A.; Bosco, D.; et al. Junctional communication of pancreatic $\beta$ cells contributes to the control of insulin secretion and glucose tolerance. J. Clin. Investig. 2000, 106, 235-243. [CrossRef]

77. Bavamian, S.; Klee, P.; Britan, A.; Populaire, C.; Caille, D.; Cancela, J.; Charollais, A.; Meda, P. Islet-cell-to-cell communication as basis for normal insulin secretion. Diabetes Obes. Metab. 2007, 9, 118-132. [CrossRef]

78. Svendsen, B.; Larsen, O.; Gabe, M.B.N.; Christiansen, C.B.; Rosenkilde, M.M.; Drucker, D.J.; Holst, J.J. Insulin secretion depends on intra-islet glucagon signaling. Cell Rep. 2018, 25, 1127-1134.e2. [CrossRef]

79. Svendsen, B.; Holst, J.J. Paracrine regulation of somatostatin secretion by insulin and glucagon in mouse pancreatic islets. Diabetologia 2020, 1-10. [CrossRef]

80. Townsend, S.E.; Gannon, M. Extracellular matrix-associated factors play critical roles in regulating pancreatic $\beta$-cell proliferation and survival. Endocrinology 2019, 160, 1885-1894. [CrossRef]

81. Staels, W.; Heremans, Y.; Heimberg, H.; De Leu, N. VEGF-A and blood vessels: A beta cell perspective. Diabetologia 2019, 62, 1961-1968. [CrossRef]

82. Sasson, A.; Rachi, E.; Sakhneny, L.; Baer, D.; Lisnyansky, M.; Epshtein, A.; Landsman, L. Islet pericytes are required for $\beta$-cell maturity. Diabetes 2016, 65, 3008-3014. [CrossRef]

83. Borden, P.; Houtz, J.; Leach, S.D.; Kuruvilla, R. Sympathetic innervation during development is necessary for pancreatic islet architecture and functional maturation. Cell Rep. 2013, 4, 287-301. [CrossRef] [PubMed]

84. Ahrén, B. Autonomic regulation of islet hormone secretion-Implications for health and disease. Diabetologia 2000, 43, 393-410. [CrossRef] [PubMed]

85. Van Gassen, N.; Staels, W.; Van Overmeire, E.; De Groef, S.; Sojoodi, M.; Heremans, Y.; Leuckx, G.; Van de Casteele, M.; Van Ginderachter, J.A.; Heimberg, H.; et al. Concise review: Macrophages: Versatile gatekeepers during pancreatic $\beta$-cell development, injury, and regeneration. Stem Cells Transl. Med. 2015, 4, 555-563. [CrossRef] [PubMed]

86. Potten, C.S.; Loeffler, M. Stem cells: Attributes, cycles, spirals, pitfalls and uncertainties. Lessons for and from the crypt. Development 1990, 110, 1001-1020. [PubMed]

87. Bruin, J.E.; Asadi, A.; Fox, J.K.; Erener, S.; Rezania, A.; Kieffer, T.J. Accelerated maturation of human stem cell-derived pancreatic progenitor cells into insulin-secreting cells in immunodeficient rats relative to mice. Stem Cell Rep. 2015, 5, 1081-1096. [CrossRef] [PubMed]

88. Kroon, E.; Martinson, L.A.; Kadoya, K.; Bang, A.G.; Kelly, O.G.; Eliazer, S.; Young, H.; Richardson, M.K.; Smart, N.G.; Cunningham, J.J.; et al. Pancreatic endoderm derived from human embryonic stem cells generates glucose-responsive insulin-secreting cells in vivo. Nat. Biotechnol. 2008, 26, 443-452. [CrossRef]

89. Hogrebe, N.J.; Augsornworawat, P.; Maxwell, K.G.; Velazco-Cruz, L.; Millman, J.R. Targeting the cytoskeleton to direct pancreatic differentiation of human pluripotent stem cells. Nat. Biotechnol. 2020, 38, 460-470. [CrossRef]

90. Augsornworawat, P.; Maxwell, K.G.; Velazco-Cruz, L.; Millman, J.R. Single-cell transcriptome profiling reveals $\beta$ cell maturation in stem cell-derived islets after transplantation. Cell Rep. 2020, 32, 108067. [CrossRef]

91. Lammert, E.; Cleaver, O.; Melton, D. Induction of pancreatic differentiation by signals from blood vessels. Science 2001, 294, 564-567. [CrossRef]

92. Anderson, S.J.; White, M.G.; Armour, S.L.; Maheshwari, R.; Tiniakos, D.; Muller, Y.D.; Berishvili, E.; Berney, T.; Shaw, J.A.M. Loss of enddifferentiated $\beta$-cell phenotype following pancreatic islet transplantation. Am. J. Transplant. 2017, 18, 750-755. [CrossRef] [PubMed] 
93. De Leu, N.; Heremans, Y.; Coppens, V.; Van Gassen, N.; Cai, Y.; D’Hoker, J.; Magenheim, J.; Salpeter, S.; Swisa, A.; Khalaileh, A.; et al. Short-term overexpression of VEGF-A in mouse beta cells indirectly stimulates their proliferation and protects against diabetes. Diabetologia 2013, 57, 140-147. [CrossRef]

94. Brissova, M.; Aamodt, K.; Brahmachary, P.; Prasad, N.; Hong, J.-Y.; Dai, C.; Mellati, M.; Shostak, A.; Poffenberger, G.; Aramandla, R.; et al. Islet microenvironment, modulated by vascular endothelial growth factor-a signaling, promotes $\beta$ cell regeneration. Cell Metab. 2014, 19, 498-511. [CrossRef] [PubMed]

95. Staels, W.; Verdonck, Y.; Heremans, Y.; Leuckx, G.; De Groef, S.; Heirman, C.; De Koning, E.; Gysemans, C.; Thielemans, K.; Baeyens, L.; et al. Vegf-A mRNA transfection as a novel approach to improve mouse and human islet graft revascularisation. Diabetologia 2018, 61, 1804-1810. [CrossRef] [PubMed]

96. Ben-David, U.; Gan, Q.-F.; Golan-Lev, T.; Arora, P.; Yanuka, O.; Oren, Y.S.; Leikin-Frenkel, A.; Graf, M.; Garippa, R.; Boehringer, M.; et al. Selective elimination of human pluripotent stem cells by an oleate synthesis inhibitor discovered in a high-throughput screen. Cell Stem Cell 2013, 12, 167-179. [CrossRef] [PubMed]

97. Tang, C.; Lee, A.S.; Volkmer, J.-P.; Sahoo, D.; Nag, D.; Mosley, A.R.; Inlay, M.A.; Ardehali, R.; Chavez, S.L.; Pera, R.R.; et al. An antibody against SSEA-5 glycan on human pluripotent stem cells enables removal of teratoma-forming cells. Nat. Biotechnol. 2011, 29, 829-834. [CrossRef]

98. Fong, C.Y.; Peh, G.S.L.; Gauthaman, K.; Bongso, A. Separation of SSEA-4 and TRA-1-60 labelled undifferentiated human embryonic stem cells from a heterogeneous cell population using magnetic-activated cell sorting (MACS) and fluorescenceactivated cell sorting (FACS). Stem Cell Rev. Rep. 2009, 5, 72-80. [CrossRef]

99. Ben-David, U.; Nudel, N.; Benvenisty, N. Immunologic and chemical targeting of the tight-junction protein Claudin-6 eliminates tumorigenic human pluripotent stem cells. Nat. Commun. 2013, 4, 1992. [CrossRef]

100. Qadir, M.M.F.; Álvarez-Cubela, S.; Belle, K.; Sapir, T.; Messaggio, F.; Johnson, K.B.; Umland, O.; Hardin, D.; Klein, D.; PérezÁlvarez, I.; et al. A double fail-safe approach to prevent tumorigenesis and select pancreatic $\beta$ cells from human embryonic stem cells. Stem Cell Rep. 2019, 12, 611-623. [CrossRef]

101. Yagyu, S.; Hoyos, V.; Del Bufalo, F.; Brenner, M.K. An inducible Caspase-9 suicide gene to improve the safety of therapy using human induced pluripotent stem cells. Mol. Ther. 2015, 23, 1475-1485. [CrossRef]

102. Oshima, M.; Pechberty, S.; Bellini, L.; Göpel, S.O.; Campana, M.; Rouch, C.; Dairou, J.; Cosentino, C.; Fantuzzi, F.; Toivonen, S.; et al. Stearoyl CoA desaturase is a gatekeeper that protects human beta cells against lipotoxicity and maintains their identity. Diabetologia 2019, 63, 395-409. [CrossRef] [PubMed]

103. Taylor, C.J.; Peacock, S.; Chaudhry, A.N.; Bradley, J.A.; Bolton, E.M. Generating an iPSC bank for HLA-matched tissue transplantation based on known donor and recipient HLA types. Cell Stem Cell 2012, 11, 147-152. [CrossRef] [PubMed]

104. De Rham, C.; Villard, J. Potential and limitation of HLA-based banking of human pluripotent stem cells for cell therapy. J. Immunol. Res. 2014, 2014, 518135. [CrossRef] [PubMed]

105. Taylor, C.J.; Bolton, E.M.; Bradley, J.A. Immunological considerations for embryonic and induced pluripotent stem cell banking. Philos. Trans. R. Soc. Lond. B Biol. Sci. 2011, 366, 2312-2322. [CrossRef] [PubMed]

106. Zhang, D.; Zhang, W.; Ng, T.W.; Wang, Y.; Liu, Q.; Gorantla, V.; Lakkis, F.; Zheng, X.X. Adoptive cell therapy using antigen-specific CD4-CD8-T regulatory cells to prevent autoimmune diabetes and promote islet allograft survival in NOD mice. Diabetologia 2011, 54, 2082-2092. [CrossRef]

107. Marek-Trzonkowska, N.; Myśliwiec, M.; Dobyszuk, A.; Grabowska, M.; Techmańska, I.; Juścińska, J.; Wujtewicz, M.A.; Witkowski, P.; Młynarski, W.; Balcerska, A.; et al. Administration of CD4+CD25highCD127- regulatory T cells preserves $\beta$-cell function in type 1 diabetes in children. Diabetes Care 2012, 35, 1817-1820. [CrossRef]

108. Marek-Trzonkowska, N.; Myśliwiec, M.; Dobyszuk, A.; Grabowska, M.; Derkowska, I.; Juścińska, J.; Owczuk, R.; Szadkowska, A.; Witkowski, P.; Młynarski, W.; et al. Therapy of type 1 diabetes with CD4+CD25highCD127- regulatory T cells prolongs survival of pancreatic islets-Results of one year follow-up. Clin. Immunol. 2014, 153, 23-30. [CrossRef]

109. Tang, Q.; Bluestone, J.A. Regulatory T-cell therapy in transplantation: Moving to the clinic. Cold Spring Harb. Perspect. Med. 2013, 3, a015552. [CrossRef]

110. Ferreira, L.M.R.; Muller, Y.D.; Bluestone, J.A.; Tang, Q. Next-generation regulatory T cell therapy. Nat. Rev. Drug Discov. 2019, 18, 749-769. [CrossRef]

111. Lim, D.; Sreekanth, V.; Cox, K.J.; Law, B.K.; Wagner, B.K.; Karp, J.M.; Choudhary, A. Engineering designer beta cells with a CRISPR-Cas9 conjugation platform. Nat. Commun. 2020, 11, 1-11. [CrossRef]

112. Carter, J.D.; Ellett, J.D.; Chen, M.; Smith, K.M.; Fialkow, L.B.; McDuffie, M.J.; Tung, K.S.; Nadler, J.L.; Yang, Z. Viral IL-10-mediated immune regulation in pancreatic islet transplantation. Mol. Ther. 2005, 12, 360-368. [CrossRef] [PubMed]

113. English, K. Mesenchymal stem cells to promote islet transplant survival. Curr. Opin. Organ. Transplant. 2016, 21, 568-573. [CrossRef] [PubMed]

114. Ben Nasr, M.; Vergani, A.; Avruch, J.; Liu, L.; Kefaloyianni, E.; D’Addio, F.; Tezza, S.; Corradi, D.; Bassi, R.; Valderrama-Vasquez, A.; et al. Co-transplantation of autologous MSCs delays islet allograft rejection and generates a local immunoprivileged site. Acta Diabetol. 2015, 52, 917-927. [CrossRef] [PubMed]

115. Xu, D.M.; Yu, X.F.; Zhang, D.; Zhang, M.X.; Zhou, J.F.; Tan, P.H.; Ding, Y. Mesenchymal stem cells differentially mediate regulatory $\mathrm{T}$ cells and conventional effector $\mathrm{T}$ cells to protect fully allogeneic islet grafts in mice. Diabetologia 2012, 55, 1091-1102. [CrossRef] [PubMed] 
116. Longoni, B.; Szilagyi, E.; Quaranta, P.; Paoli, G.T.; Tripodi, S.; Urbani, S.; Mazzanti, B.; Rossi, B.; Fanci, R.; Demontis, G.C.; et al. Mesenchymal stem cells prevent acute rejection and prolong graft function in pancreatic islet transplantation. Diabetes Technol. Ther. 2010, 12, 435-446. [CrossRef]

117. Berman, D.M.; Willman, M.A.; Han, D.; Kleiner, G.; Kenyon, N.M.; Cabrera, O.; Karl, J.A.; Wiseman, R.W.; O'Connor, D.H.; Bartholomew, A.M. Mesenchymal stem cells enhance allogeneic islet engraftment in nonhuman primates. Diabetes 2010, 59, 2558-2568. [CrossRef]

118. Arzouni, A.A.; Vargas-Seymour, A.; Nardi, N.; King, A.J.F.; Jones, P. Using mesenchymal stromal cells in islet transplantation. Stem Cells Transl. Med. 2018, 7, 559-563. [CrossRef]

119. Arzouni, A.A.; Vargas-Seymour, A.; Rackham, C.L.; Dhadda, P.; Huang, G.-C.; Choudhary, P.; Nardi, N.; King, A.J.; Jones, P. Mesenchymal stromal cells improve human islet function through released products and extracellular matrix. Clin. Sci. 2017, 131, 2835-2845. [CrossRef]

120. Rackham, C.L.; Amisten, S.; Persaud, S.; King, A.J.; Jones, P. Mesenchymal stromal cell secretory factors induce sustained improvements in islet function pre- and post-transplantation. Cytotherapy 2018, 20, 1427-1436. [CrossRef]

121. Mandal, P.K.; Ferreira, L.M.R.; Collins, R.; Meissner, T.B.; Boutwell, C.L.; Friesen, M.; Vrbanac, V.; Garrison, B.S.; Stortchevoi, A.; Bryder, D.; et al. Efficient ablation of genes in human hematopoietic stem and effector cells using CRISPR/Cas9. Cell Stem Cell 2014, 15, 643-652. [CrossRef]

122. Mattapally, S.; Pawlik, K.M.; Fast, V.G.; Zumaquero, E.; Lund, F.E.; Randall, T.D.; Townes, T.M.; Zhang, J. Human leukocyte antigen class I and II knockout human induced pluripotent stem cell-derived cells: Universal donor for cell therapy. J. Am. Heart Assoc. 2018, 7, e010239. [CrossRef] [PubMed]

123. Han, X.; Wang, M.; Duan, S.; Franco, P.J.; Kenty, J.H.-R.; Hedrick, P.; Xia, Y.; Allen, A.; Ferreira, L.M.R.; Strominger, J.L.; et al. Generation of hypoimmunogenic human pluripotent stem cells. Proc. Natl. Acad. Sci. USA 2019, 116, 10441-10446. [CrossRef] [PubMed]

124. Wang, D.; Quan, Y.; Yan, Q.; Morales, J.E.; Wetsel, R.A. Targeted disruption of the $\beta 2$-microglobulin gene minimizes the immunogenicity of human embryonic stem cells. Stem Cells Transl. Med. 2015, 4, 1234-1245. [CrossRef] [PubMed]

125. Batra, L.; Shrestha, P.; Zhao, H.; Woodward, K.B.; Togay, A.; Tan, M.; Grimany-Nuno, O.; Malik, M.T.; Coronel, M.M.; García, A.J.; et al. Localized Immunomodulation with PD-L1 results in sustained survival and function of allogeneic islets without chronic immunosuppression. J. Immunol. 2020, 204, 2840-2851. [CrossRef] [PubMed]

126. Rong, Z.; Wang, M.; Hu, Z.; Stradner, M.; Zhu, S.; Kong, H.; Yi, H.; Goldrath, A.; Yang, Y.-G.; Xu, Y.; et al. An effective approach to prevent immune rejection of human ESC-derived allografts. Cell Stem Cell 2014, 14, 121-130. [CrossRef]

127. Coronel, M.M.; Martin, K.E.; Hunckler, M.D.; Barber, G.; O’Neill, E.B.; Medina, J.D.; Opri, E.; McClain, C.A.; Batra, L.; Weaver, J.D.; et al. Immunotherapy via PD-L1-presenting biomaterials leads to long-term islet graft survival. Sci. Adv. 2020, 6, eaba5573. [CrossRef] [PubMed]

128. Cabello-Kindelan, C.; Mackey, S.; Sands, A.; Rodriguez, J.; Vazquez, C.; Pugliese, A.; Bayer, A.L. Immunomodulation followed by antigen-specific treg infusion controls islet autoimmunity. Diabetes 2019, 69, 215-227. [CrossRef] [PubMed]

129. Szot, G.L.; Yadav, M.; Lang, J.; Kroon, E.; Kerr, J.; Kadoya, K.; Brandon, E.P.; Baetge, E.E.; Bour-Jordan, H.; Bluestone, J.A. Tolerance induction and reversal of diabetes in mice transplanted with human embryonic stem cell-derived pancreatic endoderm. Cell Stem Cell 2015, 16, 148-157. [CrossRef]

130. Desai, T.; Shea, L.D. Advances in islet encapsulation technologies. Nat. Rev. Drug Discov. 2017, 16, 338-350. [CrossRef]

131. Song, S.; Roy, S. Progress and challenges in macroencapsulation approaches for type 1 diabetes (T1D) treatment: Cells, biomaterials, and devices. Biotechnol. Bioeng. 2016, 113, 1381-1402. [CrossRef]

132. Smithies, O.; Gregg, R.G.; Boggs, S.S.; Koralewski, M.A.; Kucherlapati, R.S. Insertion of DNA sequences into the human chromosomal $\beta$-globin locus by homologous recombination. Nature 1985, 317, 230-234. [CrossRef] [PubMed]

133. Hattersley, A.T.; Patel, K.A. Precision diabetes: Learning from monogenic diabetes. Diabetologia 2017, 60, 769-777. [CrossRef]

134. Vethe, H.; Bjørlykke, Y.; Ghila, L.; Paulo, J.A.; Scholz, H.; Gygi, S.P.; Chera, S.; Ræder, H. Probing the missing mature $\beta$-cell proteomic landscape in differentiating patient iPSC-derived cells. Sci. Rep. 2017, 7, 4780. [CrossRef] [PubMed]

135. Edghill, E.L.; Bingham, C.; Ellard, S.; Hattersley, A.T. Mutations in hepatocyte nuclear factor-1 and their related phenotypes. J. Med. Genet. 2005, 43, 84-90. [CrossRef] [PubMed]

136. Teo, A.K.; Lau, H.H.; Valdez, I.A.; Dirice, E.; Tjora, E.; Raeder, H.; Kulkarni, R.N. Early developmental perturbations in a human stem cell model of MODY5/HNF1B pancreatic hypoplasia. Stem Cell Rep. 2016, 6, 357-367. [CrossRef]

137. Cardenas-Diaz, F.L.; Osorio-Quintero, C.; Diaz-Miranda, M.A.; Kishore, S.; Leavens, K.; Jobaliya, C.; Stanescu, D.; Ortiz-Gonzalez, X.R.; Yoon, C.; Chen, C.S.; et al. Modeling monogenic diabetes using human ESCs reveals developmental and metabolic deficiencies caused by mutations in HNF1A. Cell Stem Cell 2019, 25, 273-289.e5. [CrossRef]

138. Rubio-Cabezas, O.; Codner, E.; Flanagan, S.E.; Gómez, J.L.; Ellard, S.; Hattersley, A.T. Neurogenin 3 is important but not essential for pancreatic islet development in humans. Diabetologia 2014, 57, 2421-2424. [CrossRef]

139. Sayar, E.; Islek, A.; Yilmaz, A.; Akçam, M.; Flanagan, S.E.; Artan, R. Extremely rare cause of congenital diarrhea: Enteric anendocrinosis. Pediatr. Int. 2013, 55, 661-663. [CrossRef]

140. Pinney, S.E.; Oliverkrasinski, J.M.; Ernst, L.M.; Hughes, N.; Patel, P.; Stoffers, D.A.; Russo, P.; De León, D.D. Neonatal diabetes and congenital malabsorptive diarrhea attributable to a novel mutation in the human Neurogenin-3 gene coding sequence. $J$. Clin. Endocrinol. Metab. 2011, 96, 1960-1965. [CrossRef] 
141. Wang, J.; Cortina, G.; Wu, S.V.; Tran, R.; Cho, J.-H.; Tsai, M.-J.; Bailey, T.J.; Jamrich, M.; Ament, M.E.; Treem, W.R.; et al. Mutant Neurogenin-3 in congenital malabsorptive diarrhea. N. Engl. J. Med. 2006, 355, 270-280. [CrossRef]

142. McGrath, P.S.; Watson, C.L.; Ingram, C.; Helmrath, M.A.; Wells, J.M. The basic helix-loop-helix transcription factor NEUROG3 Is required for development of the human endocrine pancreas. Diabetes 2015, 64, 2497-2505. [CrossRef] [PubMed]

143. De Franco, E.; Ellard, S. Genome, exome, and targeted next-generation sequencing in neonatal diabetes. Pediatr. Clin. North Am. 2015, 62, 1037-1053. [CrossRef] [PubMed]

144. Saarimäki-Vire, J.; Balboa, D.; Russell, M.A.; Saarikettu, J.; Kinnunen, M.; Keskitalo, S.; Malhi, A.; Valensisi, C.; Andrus, C.; Eurola, S.; et al. An activating STAT3 mutation causes neonatal diabetes through premature induction of pancreatic differentiation. Cell Rep. 2017, 19, 281-294. [CrossRef] [PubMed]

145. Shimomura, K.; Girard, C.A.; Proks, P.; Nazim, J.; Lippiat, J.D.; Cerutti, F.; Lorini, R.; Ellard, S.; Hattersley, A.T.; Barbetti, F.; et al. Mutations at the same residue (R50) of Kir6.2 (KCNJ11) that cause neonatal diabetes produce different functional effects. Diabetes 2006, 55, 1705-1712. [CrossRef]

146. Massa, O.; Iafusco, D.; D’Amato, E.; Gloyn, A.L.; Hattersley, A.T.; Pasquino, B.; Tonini, G.; Dammacco, F.; Zanette, G.; Meschi, F.; et al. KCNJ11 activating mutations in Italian patients with permanent neonatal diabetes. Hum. Mutat. 2004, 25, 22-27. [CrossRef]

147. Proks, P.; Antcliff, J.F.; Lippiat, J.D.; Gloyn, A.L.; Hattersley, A.T.; Ashcroft, F.M. Molecular basis of Kir6.2 mutations associated with neonatal diabetes or neonatal diabetes plus neurological features. Proc. Natl. Acad. Sci. USA 2004, 101, 17539-17544. [CrossRef]

148. Zeng, H.; Guo, M.; Zhou, T.; Tan, L.; Chong, C.N.; Zhang, T.; Dong, X.; Xiang, J.Z.; Yu, A.S.; Yue, L.; et al. An isogenic human ESC platform for functional evaluation of genome-wide-association-study-identified diabetes genes and drug discovery. Cell Stem Cell 2016, 19, 326-340. [CrossRef]

149. Allen, H.L.; The International Pancreatic Agenesis Consortium; Flanagan, S.E.; Shaw-Smith, C.; De Franco, E.; Akerman, I.; Caswell, R.; Ferrer, J.; Hattersley, A.T.; Ellard, S. GATA6 haploinsufficiency causes pancreatic agenesis in humans. Nat. Genet. 2012, 44, 20-22. [CrossRef]

150. Shaw-Smith, C.; De Franco, E.; Allen, H.L.; Batlle, M.; Flanagan, S.E.; Borowiec, M.; Taplin, C.E.; Velden, J.V.A.-V.D.; CruzRojo, J.; De Nanclares, G.P.; et al. GATA4 mutations are a cause of neonatal and childhood-onset diabetes. Diabetes 2014, 63, 2888-2894. [CrossRef]

151. Tiyaboonchai, A.; Cardenas-Diaz, F.L.; Ying, L.; Maguire, J.A.; Sim, X.; Jobaliya, C.; Gagne, A.L.; Kishore, S.; Stanescu, D.E.; Hughes, N.; et al. GATA6 plays an important role in the induction of human definitive endoderm, development of the pancreas, and functionality of pancreatic $\beta$ cells. Stem Cell Rep. 2017, 8, 589-604. [CrossRef]

152. Shi, Z.-D.; Lee, K.; Yang, D.; Amin, S.; Verma, N.; Li, Q.V.; Zhu, Z.; Soh, C.-L.; Kumar, R.; Evans, T.; et al. Genome editing in hPSCs reveals GATA6 haploinsufficiency and a genetic interaction with GATA4 in human pancreatic development. Cell Stem Cell 2017, 20, 675-688.e6. [CrossRef] [PubMed]

153. Huopio, H.; Miettinen, P.J.; Ilonen, J.; Nykänen, P.; Veijola, R.; Keskinen, P.; Näntö-Salonen, K.; Vangipurapu, J.; Raivo, J.; Stančáková, A.; et al. Clinical, genetic, and biochemical characteristics of early-onset diabetes in the Finnish population. J. Clin. Endocrinol. Metab. 2016, 101, 3018-3026. [CrossRef] [PubMed]

154. Støy, J.; Steiner, D.F.; Park, S.-Y.; Ye, H.; Philipson, L.H.; Bell, G.I. Clinical and molecular genetics of neonatal diabetes due to mutations in the insulin gene. Rev. Endocr. Metab. Disord. 2010, 11, 205-215. [CrossRef] [PubMed]

155. Colombo, C.; Porzio, O.; Liu, M.; Massa, O.; Vasta, M.; Salardi, S.; Beccaria, L.; Monciotti, C.; Toni, S.; Pedersen, O.; et al. Seven mutations in the human insulin gene linked to permanent neonatal/infancy-onset diabetes mellitus. J. Clin. Investig. 2008, 118, 2148-2156. [CrossRef] [PubMed]

156. Liu, M.; Hodish, I.; Haataja, L.; Lara-Lemus, R.; Rajpal, G.; Wright, J.; Arvan, P. Proinsulin misfolding and diabetes: Mutant INS gene-induced diabetes of youth. Trends Endocrinol. Metab. 2010, 21, 652-659. [CrossRef]

157. Balboa, D.; Saarimäki-Vire, J.; Borshagovski, D.; Survila, M.; Lindholm, P.; Galli, E.; Eurola, S.; Ustinov, J.; Grym, H.; Huopio, H.; et al. Insulin mutations impair beta-cell development in a patient-derived iPSC model of neonatal diabetes. eLife 2018, 7. [CrossRef]

158. De Franco, E.; Lytrivi, M.; Ibrahim, H.; Montaser, H.; Wakeling, M.N.; Fantuzzi, F.; Patel, K.; Demarez, C.; Cai, Y.; Igoillo-Esteve, M.; et al. YIPF5 mutations cause neonatal diabetes and microcephaly through endoplasmic reticulum stress. J. Clin. Invest. 2020, 130, 6338-6353. [CrossRef]

159. Urano, F. Wolfram syndrome: Diagnosis, management, and treatment. Curr. Diabetes Rep. 2016, 16, 1-8. [CrossRef]

160. Marshall, B.; Permutt, M.A.; Paciorkowski, A.R.; Hoekel, J.; Karzon, R.; Wasson, J.; Viehover, A.; White, N.H.; Shimony, J.; Manwaring, L.; et al. Phenotypic characteristics of early Wolfram syndrome. Orphanet J. Rare Dis. 2013, 8, 64. [CrossRef]

161. Maxwell, K.G.; Augsornworawat, P.; Velazco-Cruz, L.; Kim, M.H.; Asada, R.; Hogrebe, N.J.; Morikawa, S.; Urano, F.; Millman, J.R. Gene-edited human stem cell-derived $\beta$ cells from a patient with monogenic diabetes reverse preexisting diabetes in mice. Sci. Transl. Med. 2020, 12, eaax9106. [CrossRef]

162. Campuzano, V.; Montermini, L.; Moltò, M.D.; Pianese, L.; Cossée, M.; Cavalcanti, F.; Monros, E.; Rodius, F.; Duclos, F.; Monticelli, A.; et al. Friedreich's ataxia: Autosomal recessive disease caused by an intronic GAA triplet repeat expansion. Science 1996, 271, 1423-1427. [CrossRef]

163. Al-Mahdawi, S.; Pinto, R.M.; Ismail, O.; Varshney, D.; Lymperi, S.; Sandi, C.; Trabzuni, D.; Pook, M.A. The Friedreich ataxia GAA repeat expansion mutation induces comparable epigenetic changes in human and transgenic mouse brain and heart tissues. Hum. Mol. Genet. 2007, 17, 735-746. [CrossRef] [PubMed] 
164. Babcock, M.; Yang, J.; Liu, X.; Bhalla, K.; Kim, C.N.; Ibrado, A.M.; Cai, J.; Peng, T.-I.; Jones, D.P.; Wang, X. Regulation of mitochondrial iron accumulation by Yfh1p, a putative homolog of frataxin. Science 1997, 276, 1709-1712. [CrossRef] [PubMed]

165. Rötig, A.; De Lonlay, P.; Chretien, D.; Foury, F.; Koenig, M.; Sidi, D.; Munnich, A.; Rustin, P. Aconitase and mitochondrial iron-sulphur protein deficiency in Friedreich ataxia. Nat. Genet. 1997, 17, 215-217. [CrossRef]

166. Igoillo-Esteve, M.; Oliveira, A.F.; Cosentino, C.; Fantuzzi, F.; Demarez, C.; Toivonen, S.; Hu, A.; Chintawar, S.; Lopes, M.; Pachera, N.; et al. Exenatide induces frataxin expression and improves mitochondrial function in Friedreich ataxia. JCI Insight 2020, 5. [CrossRef] [PubMed] 